\title{
Histone Acetylation Modifiers in the Pathogenesis of Malignant Disease
}

\author{
Ulrich Mahlknecht and Dieter Hoelzer \\ Department of Hematology/Oncology, University of Frankfurt Medical Center, \\ Frankfurt, Germany
}

\begin{abstract}
Chromatin structure is gaining increasing attention as a potential target in the treatment of cancer. Relaxation of the chromatin fiber facilitates transcription and is regulated by two competing enzymatic activities, histone acetyltransferases (HATs) and histone deacetylases (HDACs), which modify the acetylation state of histone proteins and other promoter-bound transcription factors. While HATs, which are frequently part of multisubunit coactivator complexes, lead to the relaxation of chromatin structure and transcriptional activation, HDACs tend to associate with multisubunit corepressor complexes, which result in chromatin condensation and transcriptional repression of specific target genes. HATs and HDACs are known to be involved both in the pathogenesis as well as in the suppression of cancer. Some of the genes encoding these enzymes have been shown to be rearranged in the context of chromosomal translocations in
\end{abstract}

human acute leukemias and solid tumors, where fusions of regulatory and coding regions of a variety of transcription factor genes result in completely new gene products that may interfere with regulatory cascades controlling cell growth and differentiation. On the other hand, some histone acetylation-modifying enzymes have been located within chromosomal regions that are particularly prone to chromosomal breaks. In these cases gains and losses of chromosomal material may affect the availability of functionally active HATs and HDACs, which in turn disturbs the tightly controlled equilibrium of histone acetylation. We review herein the recent achievements, which further help to elucidate the biological role of histone acetylation modifying enzymes and their potential impact on our current understanding of the molecular changes involved in the development of solid tumors and leukemias.
DNA in chromatin is organized in arrays of nucleosomes, where two copies of each histone protein- $\mathrm{H} 2 \mathrm{~A}, \mathrm{H} 2 \mathrm{~B}, \mathrm{H} 3$, and $\mathrm{H} 4-$ are assembled into an octamer that has approximately 146 base pairs of DNA wrapped around it in 1.8 turns to form a nucleosome. The nucleosome is an invariant component of euchromatin and hete-

Address correspondence and reprint requests to: Ulrich Mahlknecht, MD, PhD, University of Frankfurt Medical Center, Department of Hematology/Oncology, Theodor-Stern-Kai 7, D-60590 Frankfurt, Germany. Phone: +49-69-6301-5235. Fax: +49-69-6301-6131.

E-mail: Mahlknecht@em.uni-frankfurt.de rochromatin in the interphase nucleus, and of mitotic chromosomes. This highly conserved nucleoprotein complex occurs fundamentally every $200 \pm 40 \mathrm{bp}$ throughout all eukaryotic genomes (1). During mitosis, the tightly packed metaphase chromosomes need to be accurately distributed between two daughter cells, while the DNA has to be accessible to various enzymatic machineries during interphase, when DNA is replicated, specific parts are transcribed, and mutated DNA segments are repaired. Under these circumstances, the nucleosomal architecture represents a major structural obstacle that 
limits the access of factors to nucleosomebound DNA (2). The interaction of DNA with histone proteins is highly complex and mayat least in part-be explained by electrostatic interactions between negatively charged phosphate groups in the DNA backbone and positively charged amino acids in the histone proteins (3-5). A number of post-translational modifications of the histone components of chromatin, including acetylation, phosphorylation, ubiquitination, methylation, and ADPribosylation, which altogether affect transcriptional regulation, have been described (6-8). However, our focus in this review is on the role of histone modification through acetylation in the pathogenesis of cancer.

First observations linking transcriptional activity with histone acetylation and deacetylation of the $\varepsilon$-amino groups of conserved lysine residues, which are present in the amino terminal tails of all four core histones (H2A, H2B, H3, and $\mathrm{H} 4$ ), were made more than three decades ago (9). These observations have been reinforced by studies that demonstrated transcriptionally active euchromatin domains to be highly acetylated and/or hypomethylated (9-12), while densely methylated inactive DNA has been associated with hypoacetylated histone proteins $(9,13,14)$. Notably, most DNA in mammals is methylated at $\mathrm{CpG}$ dinucleotides, with the exception of promoter elements, which contain undermethylated $\mathrm{CpG}$ islands (15). MethylCpG binding protein 2 (MeCP2) is a protein that recognizes methylated DNA and interacts with histone deacetylases, which are part of the mSIN3A/histone deacetylases (HDAC) multisubunit repressor complex. This suggests that MeCP2 mediates silencing of methylated DNA through deacetylation (16-18) (Fig. 1).

It took more than three decades to test the validity of the hypothesis that linked transcriptional activity with the post-translational modification of histone proteins, following the identification of the regulators of histone acetylation, histone acetyltransferases, and histone deacetylases (19). These enzymes allow reversible modification of histone proteins through the addition or removal of acetyl groups, which alter the strength of the bonding between histones and DNA, thereby modifying the regulation of biological processes such as DNA replication and repair, gene expression, chromatin assembly, condensation, and cell division (see also 20,21 for reviews). In addition to the effect of histone acetyltransferases (HATs) and HDACs on the charge of the histone octamer, these enzymes may also directly alter the activity of basal and sequence-specific transcription factors as well as other cellular regulators (cell-cycle regulators, signaling cascades, etc.) (Fig. 2) $(5,22,23)$.

\section{Histone Modification and Transcriptional Control}

The work of many investigators during the last few years has contributed to almost explosive advances in our understanding of the molecular details of transcriptional regulation and chromatin modification within the context of the highly complex interplay of protein-DNA binding factors and protein-protein interactions. It is now becoming increasingly obvious that most enzymes that regulate the acetylation state of histone proteins and other promoterbound transcription factors (i.e., HATs and HDACs) exert their enzymatic activities as members of large multisubunit protein complexes. A deregulation of the tightly controlled equilibrium of acetylation and deacetylation plays a causative role in the generation as well as in the suppression of several types of cancer $(20,24-27)$. Depending on the specific target promotors, hyperacetylation and deacetylation may exert contradictive effects on gene expression (28) and suppress tumorigenesis in some cases, while they facilitate cancer development in others. This could be either (1) a consequence of chromosomal translocations, where histone acetylation modifiers may be fused to or recruited by a newly generated transcription factor hybrid protein, which alters the expression of specific target genes, or (2) an effect of overall changes in the concentrations of functionally available histone acetylation modifiers.

\section{Histone Acetyltransferases}

The first HAT gene to be cloned was HATl, a yeast histone acetyltransferase, initially identified as a temperature-sensitive mutant lacking the capability to acetylate specific lysine residues of the Histone $\mathrm{H} 4$ peptide (29-31). This was followed by the discovery of a homolog of the yeast HAT GCN5 (general control of amino acid synthesis) in Tetrahymena, which was identified by virtue of its HAT enzymatic activity (19). GCN5 is known to be the 

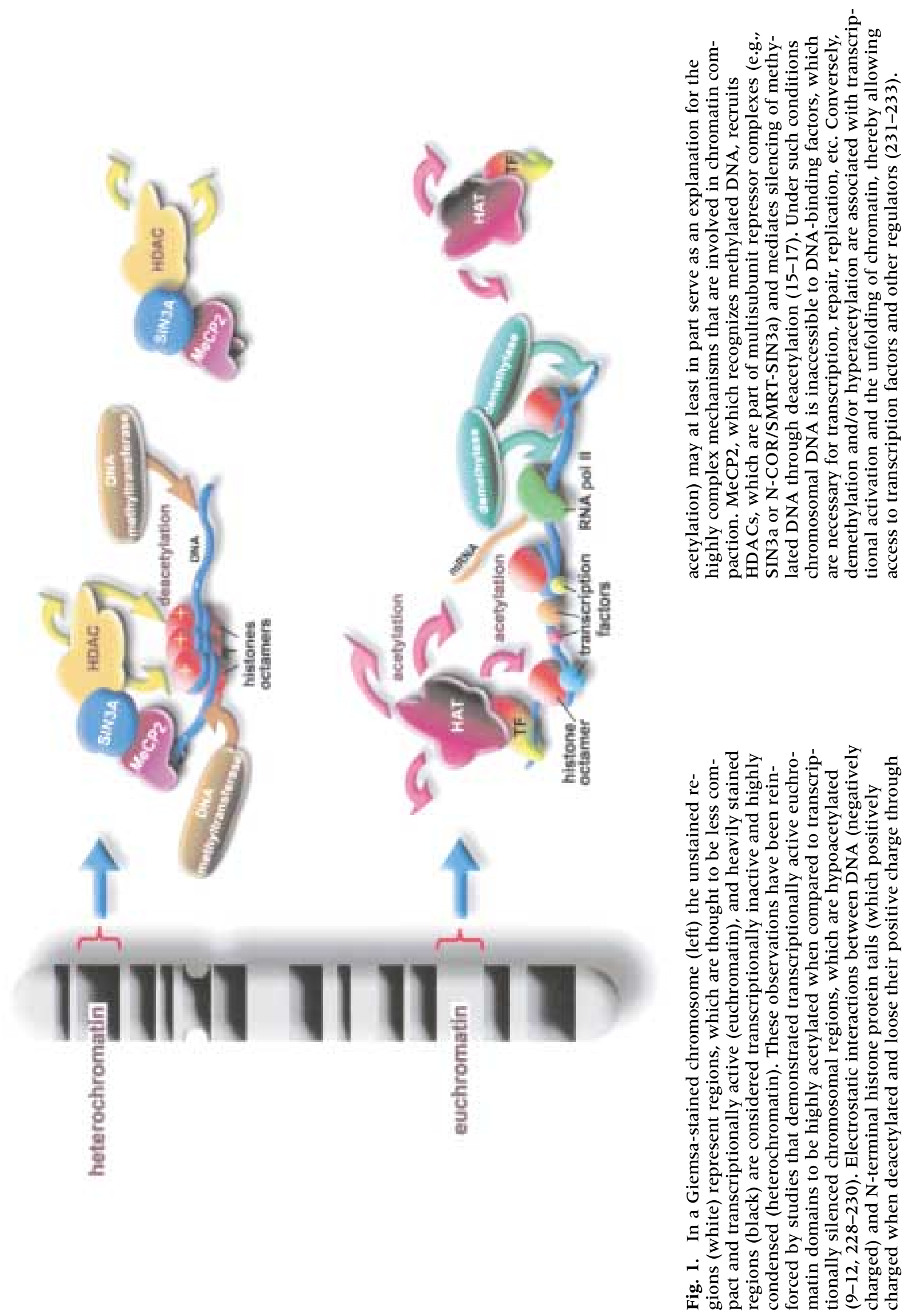

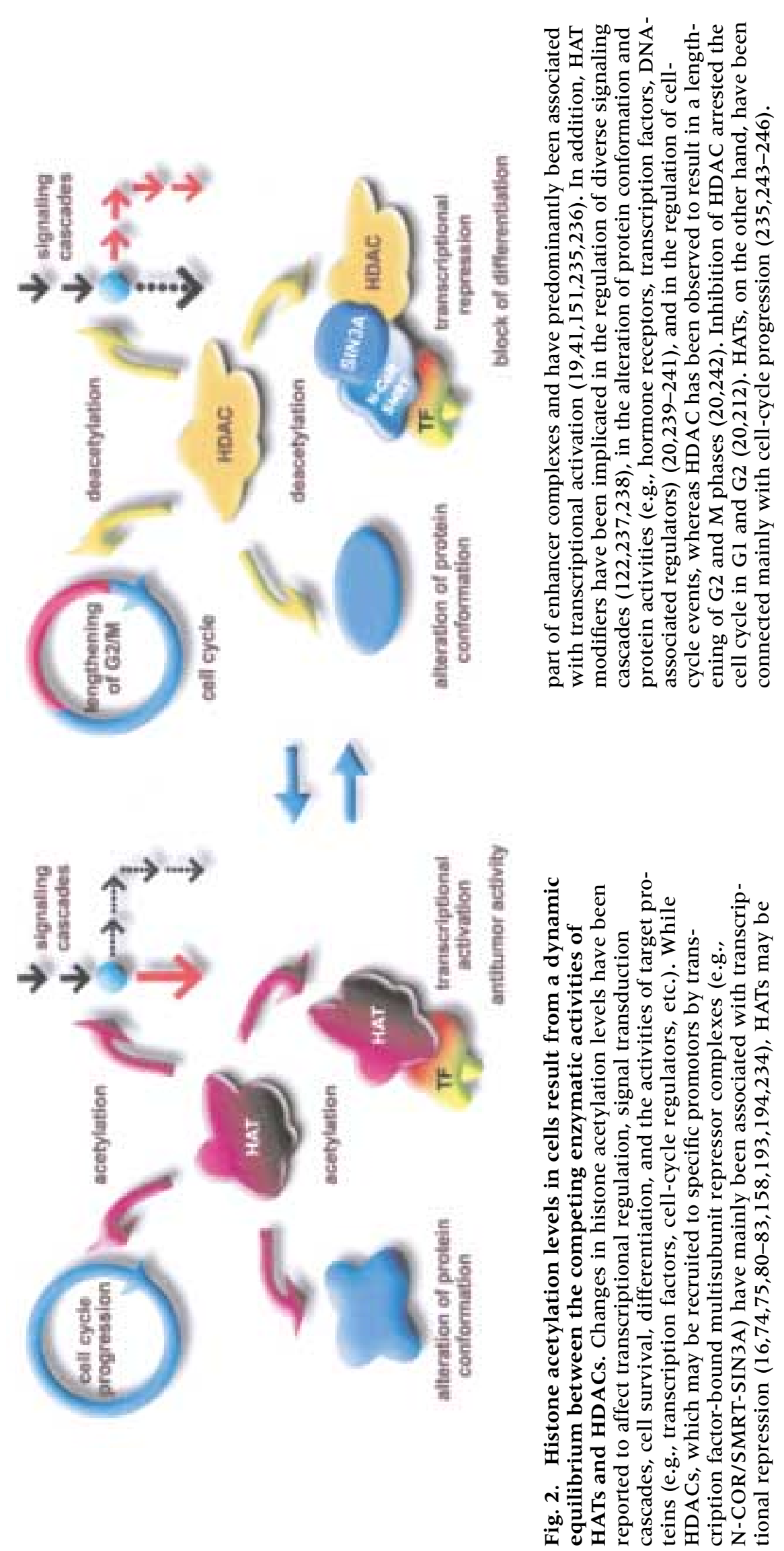
catalytic unit of both the yeast ADA (Ada2Ada3-Gcn5) and SAGA (SPT-ADA-GCN5acetyltransferase) coactivator complexes, which exert HAT activity (32-34) and of the human SAGA-homolog STAGA (SPT3-TAF ${ }_{\text {II }}$ 1-GCN5 acetyltransferase) (35). Since then, a number of enzymes with HAT activity have been identified in humans, including CREB binding protein (CBP)/p300 (36-38); p300/CBP associated factor (p/CAF) $(36,38,39)$; the pl60 family of proteins (NCOAl-3) (40-43); the MYST family, which includes the human proteins monocytic leukemia zinc finger (MOZ), monocytic leukemia zinc finger protein-related factor (MORF), Tat interacting protein 60 (Tip60), and histone acetyltransferase binding to ORC (HBOl) (44-51); $\mathrm{hTF}_{\text {III }} \mathrm{C} 90$ (52,53); and $\mathrm{TAF}_{\mathrm{II}} 250$ (54). For the HAT proteins MOF (45), HAT-A4 (55), Esal (45), NuA3/NuA4 (56), and Elp3 (57), a human homolog has not been identified to date.

So far, only one report for a HAT knock-out is available, where $p 300$ nullizygous mice were found to die early after gestation, exhibiting defects in neurulation, cell proliferation, and heart development and where heterozygous mice also revealed considerable embryonic lethality. In the same study, cells derived from $p 300$-deficient embryos displayed specific transcriptional defects and proliferated poorly. Mice that were double heterozygous for $p 300$ and $C B P$ were consistently associated with embryonic death (58). Taken together, HATs can be subdivided into two broad categories, type A and type B, by virtue of their subcellular localization. While type A HATs, which are located in the nucleus, essentially are believed to acetylate chromosomal histones, thereby playing important roles in the regulation of gene expression, type B HATs are found in the cytoplasm, where they acetylate cytoplasmic histones prior to chromatin assembly (for review see 20,21,27,59,60) (Table 1).

\section{Histone Deacetylases}

First links between the modification of histone acetylation in conjunction with transcriptional activity were observed in the early 1960s (9). In the 1970s, an inhibition of histone deacetylase activity was shown to result in the accumulation of acetylated histones in vivo (61). Finally, the biochemical fractionation of yeast extracts led to the discovery of two distinct yeast histone deacetylating activities, HDA, the catalytic subunit of a 350-kDa histone deacetylase complex, which contains the histone deacetylase 1 (HDAl) protein and HDB, the catalytic subunit of a $600-\mathrm{kDa}$ histone deacetylase complex, which contains reduced potassium dependency 3 (RPD3). HDAl and RPD3 share a significant degree of sequence homology at the protein level. Both proteins act mainly as negative regulators of transcription. They may however, counteract repression at telomeric loci, where the general hyperacetylation of histones is associated with gene activation. Whether this observation, that HDAC enzymes repress genes in some parts of the genome while they activate transcription in other parts, reflects indirect mechanisms (e.g., reduction of the expression of genes, which encode other repressor proteins) or direct, genespecific effects, remains still to be elucidated $(28,62,63)$. Functionally, HDAl and RPD3 have nonoverlapping effects on the modulation of lifespan: while the deletion of RPD 3 was observed to extend life in yeast, this was not the case for $H D A 1$, unless it was combined with the deletion of additional genes (e.g., SIR3). The simultaneous deletion of both HDA1 and RPD3 has been shown to decrease lifespan and because the expression of both enzymes declines with age, this could provide a possible explanation for the increase in mortality during senescence (64). While HDA activity in yeast is strongly inhibited by $\mathrm{Zn}^{2+}$, spermine, and spermidine (65), RPD3 mutants are highly sensitive to cycloheximide (63). Null mutants of both HDA1 and RPD 3 are viable and result in a general increase of histone acetylation and gene expression, except for genes located in telomeric regions, where histone acetylation has been associated with silencing (28).

Using trapoxin, a potent histone deacetylase inhibitor, as a bait in an affinity matrix, HDACl, the first human RPD3 ortholog, was purified (66). HDAC2, a closely related protein, was found when screening studies for corepressors that interact with YYl, a transcription repressor/activator, were performed (67). Moreover, HOS1, HOS2, and HOS3, three yeast histone deacetylases, which are homologous to both HDAl and RPD3, were identified (28). In most cases, RPD3 is physically associated with SIN3 (also referred to as RPDl) and exerts its transcriptional repression function within a 2-MDa corepressor complex, which is distinct from the 600-kDa HDB complex described above $(63,68-71)$. This corepressor complex is recruited to promoters by sequence-specific 
Table 1. Human histone acetyltransferases

\begin{tabular}{|c|c|c|c|c|c|c|c|c|c|c|}
\hline \multirow[b]{2}{*}{ Family } & \multirow[b]{2}{*}{ Members } & \multirow{2}{*}{$\begin{array}{l}\text { Alternate } \\
\text { Symbols }\end{array}$} & \multirow{2}{*}{$\begin{array}{l}\text { Cytogenetic } \\
\text { Position }\end{array}$} & \multicolumn{4}{|c|}{$\begin{array}{l}\text { Histone Preference } \\
\text { (K: lysine specificity) }\end{array}$} & \multicolumn{2}{|c|}{$\begin{array}{c}\text { HAT type } \\
\text { (A: nuclear, B: } \\
\text { cytoplasmic) }\end{array}$} & \multirow[b]{2}{*}{ References } \\
\hline & & & & H2A & H2B & $\mathbf{H 3}$ & H4 & $\mathbf{A}$ & B & \\
\hline HAT & $\begin{array}{l}\text { HAT1 } \\
\text { HAT2 }\end{array}$ & - & $\begin{array}{c}2 \mathrm{q} 31.2-\mathrm{q} 33.1 \\
\text { n.a. }\end{array}$ & $\begin{array}{c}(++) \\
K_{5}\end{array}$ & & & $\begin{array}{c}++ \\
\mathrm{K}_{5,12}\end{array}$ & $(+)$ & + & $(29-31,55)$ \\
\hline GCN5 & $\begin{array}{l}G C N 5 L 1 \\
G C N 5 L 2\end{array}$ & - & $\begin{array}{c}12 q 13-q 14 \\
17 q 21\end{array}$ & & & $\begin{array}{l}+++ \\
\mathrm{K}_{14}\end{array}$ & $\begin{array}{c}+ \\
\mathrm{K}_{8,16}\end{array}$ & + & & $(19,32-35)$ \\
\hline P/CAF & $P / C A F$ & - & $3 p 24$ & & & $\begin{array}{c}++ \\
\mathrm{K}_{14}\end{array}$ & $\begin{array}{l}++ \\
\mathrm{K}_{8}\end{array}$ & + & & $(36-38,102)$ \\
\hline p300/CBP & $\begin{array}{c}p 300 \\
C B P\end{array}$ & - & $\begin{array}{l}22 q 13.2 \\
16 p 13.3\end{array}$ & $\begin{array}{l}++ \\
K_{5}\end{array}$ & $\begin{array}{c}++ \\
K_{5,12} \\
15,20\end{array}$ & $\begin{array}{c}++ \\
\mathrm{K}_{14} \\
18,23\end{array}$ & $\begin{array}{c}++ \\
K_{5,8>} \\
12,16\end{array}$ & + & & $(36-38)$ \\
\hline \multirow[t]{2}{*}{ pl60 } & $\begin{array}{l}\text { NCOA1 } \\
\text { NCOA2 }\end{array}$ & $\begin{array}{c}S R C-1 \\
\text { GRIP-1 } \\
\text { TIF2 }\end{array}$ & $\begin{array}{l}2 \mathrm{p} 23 \\
8 \mathrm{q} 13\end{array}$ & & & & & & & \\
\hline & $\mathrm{NCOA} 3$ & $\begin{array}{c}A I B 1 \\
R A C 3 \\
A C T R \\
P / C I P \\
T R A M-1\end{array}$ & $20 q 12$ & $(+)$ & $(+)$ & + & + & + & & $(40-43,104)$ \\
\hline MYST & $\begin{array}{l}\text { MOZ } \\
\text { MORF } \\
\text { HBO1 } \\
\text { Tip60 }\end{array}$ & $\begin{array}{l}- \\
- \\
-\end{array}$ & $\begin{array}{c}8 \mathrm{p} 11 \\
10 \mathrm{q} 22.2 \\
\mathrm{Xq21} \\
11\end{array}$ & ++ & & ++ & $\begin{array}{c}++ \\
\mathrm{K}_{16}\end{array}$ & + & & $(44-51)$ \\
\hline $\begin{array}{l}\mathrm{TF}_{\mathrm{II}} \mathrm{D} \\
\text { complex }\end{array}$ & $T A F_{I I} 250$ & $\begin{array}{c}T A F 2 A \\
C C G 1 \\
B A 2 R\end{array}$ & $\mathrm{Xq13}$ & & & +++ & + & + & & (54) \\
\hline $\mathrm{hTF}_{\mathrm{III}} \mathrm{C} 90$ & $h T F_{I I I} C 90$ & - & NA & & & ++ & & + & & $(52,53)$ \\
\hline
\end{tabular}

repressor proteins, including the mammalian heterodimeric repressors Mad/Max and Mxi/ Max, which are repressors in large part because of their ability to recruit the RPD3/SIN3 complex to DNA-bound regulators of transcription $(66,72-79)$, while other repressors (e.g., unliganded nuclear receptors) recruit the RPD3/SIN3 complex via SMRT (silencing mediator of retinoic acid and thyroid hormone receptors) or nuclear corepressor (N-COR) (78-82) and regulators like UME6 recognize URS 1 and bind SIN3, which in turn interacts with RPD3 $(75,83)$. RPD3, which contains the catalytic deacetylase subunit of the SIN3/RPD3 complex, is clearly required for repression by SIN3 (83). However, although it is likely that the SIN3/RPD3 complex performs multiple functions, some of which may play a more prominent role in the repression of transcription, it remains to be elucidated whether histone deacetylation per se is the primary mechanism of transcriptional repression (Table 2).
So far, seven human histone deacetylase proteins, all of which share a highly conserved catalytic domain, have been identified, of which HDAC1, HDAC2, and HDAC3 are orthologs of yeast RPD3 $(66,67,84-86)$, while HDAC4, HDAC5, HDAC6, and HDAC7 are yeast HDAl orthologs $(87,88)$. All human RPD3 orthologs that have been reported so far repress transcription when targeted to DNA via a DNA-binding domain. They all bind transcription factor YY1, which can act both as an activator and a repressor of transcription (89). Accordingly, the inhibition of HDACs by trichostatin or trapoxin is associated with the activation or repression of specific gene products (90). While mammalian HDACl and HDAC2 have been shown to interact with mSIN3 and the N-COR or SMRT corepressor complexes, which may associate additional proteins (e.g., SAP18, SAP30, RbAp48, or RbAp46), HDAC3 does not appear to be part of such multiprotein complexes (74,75,80-82,91). Unlike the other deacetylases, HDAC4, which 
Table 2. Human histone deacetylases

\begin{tabular}{|c|c|c|c|c|c|c|c|c|c|c|}
\hline \multirow[b]{2}{*}{ Family } & \multirow[b]{2}{*}{ Members } & \multirow{2}{*}{$\begin{array}{c}\text { Alternate } \\
\text { Symbols }\end{array}$} & \multirow{2}{*}{$\begin{array}{c}\text { Cytogenetic } \\
\text { Position }\end{array}$} & \multicolumn{4}{|c|}{$\begin{array}{l}\text { Histone Preference } \\
\text { (K: lysine specificity) }\end{array}$} & \multicolumn{2}{|c|}{ HD type } & \multirow[b]{2}{*}{ References } \\
\hline & & & & H2A & H2B & H3 & H4 & HDA & HDB & \\
\hline \multirow{3}{*}{$\begin{array}{l}\text { RPD3 } \\
\text { orthologs } \\
\text { (class I } \\
\text { HDACs) }\end{array}$} & $H D A C 1$ & - & $1 p 34.1$ & & & & & & & $\begin{array}{l}(28,63,66 \\
70,74,75\end{array}$ \\
\hline & $H D A C 2$ & - & $6 q 21$ & + & + & $\begin{array}{c}+ \\
K_{5,12}\end{array}$ & $\begin{array}{c}+ \\
K_{9,14}\end{array}$ & & + & $\begin{array}{c}80-83,85 \\
88,195,234\end{array}$ \\
\hline & $H D A C 3$ & - & $5 q 31.1$ & & & $16(\cdots)$ & $(\cdots)$ & & & $242,247)$ \\
\hline \multirow{4}{*}{$\begin{array}{l}\text { HDAl } \\
\text { orthologs } \\
\text { (class II } \\
\text { HDACs) }\end{array}$} & HDAC4 & $H D A C-A$ & $2 q 37.2$ & \multirow{4}{*}{+} & \multirow{4}{*}{+} & \multirow{4}{*}{+} & \multirow{4}{*}{+} & \multirow{4}{*}{+} & & \multirow{4}{*}{$\begin{array}{c}(28,87,88 \\
92,248)\end{array}$} \\
\hline & HDAC5 & $\mathrm{NY}-\mathrm{CO}-9$ & 17 & & & & & & & \\
\hline & HDAC6 & - & $\times$ & & & & & & & \\
\hline & $H D A C 7$ & MITR & $7 \mathrm{p} 15-\mathrm{p} 21$ & & & & & & & \\
\hline
\end{tabular}

belongs to the HDAl family of HDACs, has been reported to shuttle between the nucleus and the cytoplasm in a process involving active nuclear export $(87,92)$. Unfortunately, human orthologs of the yeast histone deacetylases HOS 1 (28), HOS $2(28,93)$ and HOS3 $(28,94)$ have not been reported so far.

\section{Histone Acetylation, Solid Tumors, and Leukemias: When HATs Are the Key Players}

More recently, an increasing number of disease processes have been observed to involve abnormalities of the tightly regulated interplay of acetylating and deacetylating cellular events, which are maintained by the enzymatic activities of HATs and HDACs (95-100). A decrease in the amount of functionally available HDACs (e.g., if HDAC loci are part of chromosomal deletions) or an increase of functionally active HAT enzymatic activities (e.g., if chromosomal segments, which encode HAT proteins, are amplified) may shift the equilibrium of histone acetylation toward acetylation, which in turn has an effect on conformation and activity of associated transcription factors (e.g., GATA-1, TF $\mathrm{II}$ E $\beta, \mathrm{TF}_{\mathrm{II}} \mathrm{F}, \mathrm{EKLF}$, and p53) (23) and subsequently on gene expression, interaction targets, and activities of downstream signaling pathways (28,101-104). If, by contrast,
HATs are fused to a transcription factor in the context of a chromosomal translocation (46-48, 105-110), which creates a novel chimeric protein, hyperacetylation may be confined to the target promoters of that specific transcription factor and, because transcription factors have many domains of protein-protein interaction, the transcription factor/HAT-fusion may allow acetylation of associated regulators and result in the transcriptional activation of a restricted number of genes. As a consequence, chromosomal regions that were silenced under normal conditions may now be derepressed and change the entire pattern of gene expression within affected cells: genes that were previously silenced may now be activated or even overexpressed, whereas other genes, which were previously expressed, may now secondarily be repressed $(5,28,111)$. HAT enzymes have been found amplified, translocated, overexpressed, deleted, or point mutated in several types of cancers:

An overexpression of HAT enzymatic activities has, for example, been described for the steroid receptor coactivator-1 (SRC1) homolog AIBl, which is involved in the pathogenesis of both breast and ovarian cancers. The associated HAT defect that has been described for this particular type of cancer is a more than 20-fold amplification of the chromosomal region, which contains the AIBl gene, and has been determined by fluorescence in situ hybridization (FISH) $(104,112)$. 
Changes in the availability of functionally available HATs may also directly affectfunctions and activities of nonhistone proteins, in view of the fact that some histone acetyltransferases (p300, P/CAF, and TAF250) have been described to directly acetylate general transcription factors $\left(\mathrm{TF}_{\mathrm{II}} \mathrm{F}\right.$ and $\mathrm{TF}_{\mathrm{II}} \mathrm{E} \beta$ ) (113), sequence-specific transcription factors (e.g., GATA-1 or EKLF) (114, 115), tumor suppressors (e.g., p53 or NF $\kappa B$ ) (116-118), architectural chromatin proteins (e.g., HMGI(Y)) (119), and DNA repair complexes, where it seems to increase the DNA-binding capacity of the protein $(115,116)$.

Both p300 and CBP possess HAT activity, which is partly intrinsic and partly the result of association with other proteins (e.g., p/CAF) (36-38). The CBP/p300 HAT-protein complex integrates many signaling pathways (e.g., the TGF- $\beta$ signaling pathway) $(120-122)$ and is able to interact with a series of transcription factors (e.g., CREB, c-Jun, JunB, c-Fos, Myb, MyoD, YY1, nuclear receptors and basal components of the transcriptional apparatus, etc.) (123) and to participate in the direct or indirect stimulation of transcription through scaffolding different classes of transcriptional regulators onto specific chromatin domains $(124,125)$. p300 and CBP have been envisioned as negative regulators of cell growth; mutations or translocations of the $p 300$ or of the $C B P$ genes have been found to be associated with several solid tumors (e.g., point mutations of $p 300$, which may be found in colorectal and gastric carcinomas, are usually located within the cysteine histidine-rich regions of the protein, known to play important roles in the biological activities of p300 $(121,126,127)$; loss of heterozygosity for $p 300$ in $80 \%$ of glioblastomas (128) and acute leukemias (e.g., in the M4/M5 subtype of acute myeloid leukemia [AML] where CBP is found translocated and fused to the putative acetyltransferase $\mathrm{MOZ}$ $\left[t(8 ; 16)\left(p_{11} ; p_{13}\right)\right]$, which is a human homolog of the yeast $S A S$ genes [SAS: something about silencing]) $(48,109,129)$. Remarkably, p300 mutations are located within the cysteine histidine-rich regions, which have been observed to play an important role in the biological activities of p300 (130). In addition, it has been reported that the oncogenic viral proteins ElA and SV40 are able to antagonize CBP-dependent transcription, thereby promoting cellular proliferation $(38,131-133)$.

Leukemia-associated chromosome 8 inversions of the genotype inv $(8)(\mathrm{pll} ; \mathrm{q} 13)$ characteristically fuse MOZ to TIF2/NCOA2/GRIP1 (transcriptional mediator/intermediary factor 2) (134,135), a NR (nuclear hormone receptor) coactivator that itself binds CBP/p300 $(136,137)$. The phenotype of the resulting MOZ-TIF2 fusion is therefore highly similar to the MOZ-CBP fusion.

In other leukemias, particularly therapyrelated AML, myelodysplastic syndrome, and chronic myelomonocytic leukemia, CBP may be fused to $M L L$ (mixed lineage leukemia), a gene that has been associated with the myelodysplastic syndrome $[t(11 ; 16)(q 23 ; p 13)](48,105-108)$. In both translocations (MLL-CBP and MOZ-CBP) the HAT domain of CBP remains intact within the fusion protein and because both $\mathrm{MOZ}$ and MLL have been implicated in the modification of chromatin structure, it is likely that the molecular mechanism through which the fusion proteins perturb growth is by dysregulating gene expression patterns (130).

In a separate subset of AMLs, which has been reported to be associated with therapyinduced leukemia, the $p 300$ gene was found rearranged and fused in frame with the $M L L$ gene $[t(11 ; 22)(q 23 ; q 13)](106,138)$. This suggests that alterations of CBP function may occur in the later stages of leukemogenesis, possibly as a way to eliminate cell-cycle checkpoints and apoptotic responses (130). Notably, the MLL fusion proteins described herein lack the carboxy terminal SET (suppressor of variegation) domain, which is a hall-mark of many chromatinassociated proteins $(139,140)$. The MLL SET domain interacts with the human SWI/SNF (switch defective/sucrose nonfermenting) chromatin-remodeling complex, a powerful transcriptional activator that belongs to a family of DNA-stimulated ATPases that can either disrupt the structure of nucleosome core particles or influence the mobility and spacing of nucleosome arrays $(141,142)$. Therefore, a fusion of MLL and CBP results in the dysregulation of transcription by failing to recruit SWI/SNF. Conversely, the leukemia-associated $M L L-A F 9$ and $M L L-E N L$ translocations fuse $M L L$ to genes, which encode transcriptional activators expressing carboxy terminal domains, which are highly homologous to SET and may function as distinct targets for the SWI/SNF complex 
(143-146). Somatic mutations within the SWI/ $S N F$ complex have been identified in several aggressive pediatric malignant rhabdoid tumors (147).

Humans lacking one functional allele of the $C B P$ gene, having point mutations or microdeletions within the 16 p13.3 chromosomal region that contains $C B P$, develop a condition, which has been described as "RubinsteinTaybi syndrome" (autosomal dominant). Individuals exhibiting this condition have a particular propensity for malignancy, skeletal abnormalities, and growth retardation $(128,148)$. Concordantly, CBP-heterozygous mice reveal skeletal abnormalities corresponding to the changes that are seen in Rubinstein-Taybi syndrome (149). Interestingly, in spite of apparently overlapping functions between CBP and p300, patients with Rubinstein-Taybi syndrome have an intact $p 300$ allele, which is potentially unable to sufficiently substitute for CBP $(130,150)$.

Unfortunately, it is not presently clear exactly how p300 and CBP are involved in the development of cancer. What is known, however, is that p300 and CBP, which have welldocumented activity as transcriptional activators, are important key players in cell-cycle control, within apoptotic pathways, in the promotion of differentiation, and in p53 signaling and activation $(116,124,151,152)$. In a simplified scenario the anti-oncogenic properties of p300 and CBP seem to go hand in hand with the anti-oncogenic activities that have been proposed for $\mathrm{p} 53$; since $\mathrm{p} 300$ forms a complex with p53 that exerts its anticancerogenic activity by negatively regulating cell growth. Several promoter/enhancer elements, such as the API and c-Fos elements, function in a p300-dependent manner (153), which has been correlated with a promotion of Gl-S transition, resulting thereby in cellular proliferation and potentially transformation (154). Although the formation of p53-p300 may in part be responsible for the recruitment of p300 onto some promoters, it may inhibit the transactivating effects of p300 on others (e.g., on promoters containing the DNA binding sites for the transcription factor AP1, where increased levels of p300 are able to overcome p53-mediated inhibition of AP1). Most interestingly, p53 binds to p300 in a region that is required for its intrinsic HAT activity (37). However, this region is distinct form the domains that bind to C-Jun (155), P/CAF (38), and TBP (156), all of which are important modulators of transcription. It has therefore been suggested that p 53 might function through direct protein-protein interactions via p300 and possibly also through other $\mathrm{p} 300$-associated factors (124).

It has been observed that factors like the nuclear hormone receptors (e.g., RAR/RXR) mediate transcriptional repression by recruiting HDAC complexes in their unliganded form (80-82), while they exhibit ligand-inducible transcriptional activator functions through the recruitment of HAT-coactivator complexes (p300/CAF) when hormone is bound (Fig. 3) $(4,5,40,150,157)$. Similarly, $\mathrm{E} 2 \mathrm{~F}$ and $\mathrm{Rb}$, for example, form a repressor complex, which recruits HDACl and HDAC2 $(158,159)$ and subsequently represses the cyclin E promoter. Frequently, phosphorylation is a key event that induces a conformational change within a transcription factor or other regulatory elements (e.g., $\mathrm{NF} \kappa \mathrm{B}$, the IFN $\beta$ enhancer complex or $\mathrm{Rb}$ ), which then readily recruits a HAT-coactivator complex and stimulates transcription (160-162).

\section{Histone Acetylation, Solid Tumors, and Leukemias: When HDACs Are the Key Players}

Leukemias are generally associated with characteristic chromosomal translocations, which may result either in the generation of a chimeric protein with novel functional properties or in the aberrant expression of a regulatory element. Usually, chromosomal translocations affect only one allele of a gene. Therefore, to cause a phenotypic effect, the activity of the newly generated fusion protein needs to be dominant over that of the wild-type protein. Frequently, the translocations found in leukemias target regulatory transcription factors that control cellular proliferation, survival, and differentiation and may obviate the need for multistep mutation pathways because they are observed for protooncogenes and tumor suppressor genes in solid tumors $(163,164)$. In accordance with the disease-linked HAT defects that have been described above, HDAC defects may very similarly be associated with a tumorigenic phenotype of affected cells. When HDACs are excessively available or if the amount of functionally available HATs is decreased, the balance of histone acetylation will be shifted toward deacetylation, resulting subsequently in a dysregulation 
of gene expression. Several transcriptional repressors (e.g., Mad and members of the nuclear receptor superfamily), trans-cription factors, and cellular regulators have been described to associate with HDAC activities (5).

The analysis of the transforming chimeric proteins PML-RAR $\alpha \quad[\mathrm{t}(15 ; 17)(\mathrm{q} 22 ; \mathrm{q} 21)]$ $(163,165-167)$ and PLZF-RAR $\alpha[t(11 ; 17)$ $(q 23 ; q 21)](167-170)$, which are found in different acute promyelocytic leukemias (APL), has shown a clear connection between the action of histone deacetylases and the development of cancer. In these instances the promyelocytic leukemia gene $(P M L)[\mathrm{t}(15 ; 17)$ $(\mathrm{q} 22 ; \mathrm{q} 21)]$ or the promyelocytic leukemia zinc finger gene $(P L Z F)[t(11 ; 17)(q 23 ; \mathrm{q} 21)]$ are fused to the retinoic acid receptor-alpha $(R A R \alpha)$ and are no longer responsive to physiological levels of retinoic acid $(167,171,172)$. These chromosomal changes result in a block of cellular differentiation (i.e., in the clonal expansion of cells arrested in the promyelocyte stage of development) yielding the clinical picture of an acute leukemia $(78,171,172)$. While patients featuring the $P M L-R A R \alpha[\mathrm{t}(15 ; 17)(\mathrm{q} 22 ; \mathrm{q} 21)]$ translocation, readily differentiate upon treatment with alltrans-retinoic acid (ATRA) $(78,171)$, patients having the PLZF-RAR $\alpha[\mathrm{t}(11 ; 17)(\mathrm{q} 23 ; \mathrm{q} 21)]$ type of translocation do not respond adequately to treatment with ATRA $(78,171)$. On the molecular level, RAR $\alpha$ represses target genes by tethering corepressors such as $\mathrm{N}$-COR and SMRT to promoter DNA $(78,173)$. These corepressors are part of one or more large complexes that also contain mSIN3A and HDAC proteins (5). In cells that express PML-RAR $\alpha$, retinoic acids lead to the dissociation of the SMRT-mSIN3AHDAC 1 and N-COR-mSIN3A-HDAC 1,2 complexes from $\operatorname{RAR} \alpha(97,98,172)$. By contrast, cells that express PLZF-RAR $\alpha$ have two $\mathrm{N}$-COR binding sites, one in the $\operatorname{RAR} \alpha$ region (which is responsive to retinoic acids) and one in the PLZF amino terminal region (which is nonresponsive to retinoic acids) of the fusion protein (97). Because PLZF binds N-COR and SMRT independently from $\operatorname{RAR} \alpha$, the HDAC corepressor complex is readily released from $\operatorname{RAR} \alpha$ upon treatment with retinoic acids, but not from PLZF (97). As a consequence, transcriptional repression is preserved. However, the sensitivity of PLZF to ATRA may be restored by the treatment with an HDAC inhibitor (e.g., trichostatin A, an antibiotic). The PLZF-bound HDAC corepressor complex is then readily released, allowing these leukemic cells to differentiate $(97,98,172,174,175)$.

An additional example of a translocation found in AML and that has been shown to involve HDACs is the translocation $t(8 ; 21)$ (q22; q22), which results in a fusion of $A M L$ 1 and ETO (176-178) and accounts for approximately 10-12\% of AMLs (164). Similarly, AML-1 may be fused to MTG16 (myeloid tumor gene 16) in the context of a translocation $\mathrm{t}(16 ; 21)(\mathrm{q} 24 ; \mathrm{q} 22)(179-181)$, or to EVI1, a transcriptional repressor, in association with a translocation $\mathrm{t}(3 ; 21)(\mathrm{q} 26 ; \mathrm{q} 22)(177,182$, 183). In all these translocations of $A M L-1$, the Runt homology domain, which is the region of AML-1 that interacts with both DNA and the core binding factor $\operatorname{CBF} \beta$, is preserved $(178,184,185)$. Other translocations that are frequently seen are an inversion of chromosome 16 [inv(16)] in AML, where the $C B F \beta$ gene, which forms a transcription factor complex with $A M L-1$, is fused to the smooth muscle myosin heavy chain gene MYH11 (164) and the translocation $\mathrm{t}(12 ; 21)$ (p12;q22), which is found in $15-35 \%$ of pediatric B-lineage ALLs and where a TEL$A M L 1$ gene fusion yields a novel chimeric protein $(186,187)$. The ability of $\mathrm{CBF} \beta$ to associate with AML-1, hereby increasing the affinity of AML-1 for its DNA-binding site, is retained even when chromosome 16 is inverted $(184,185)$. Because all the translocations mentioned in this paragraph $[\mathrm{t}(8 ; 21)$ $(\mathrm{q} 22 ; \mathrm{q} 22), \mathrm{t}(3 ; 21)(\mathrm{q} 26 ; \mathrm{q} 22), \mathrm{t}(12 ; 21)(\mathrm{p} 12 ;$ q22) and inv(16)] interfere with the transcriptional regulation of AML-1 responsive genes $(177,178,188-191)$, evidence emerges that transcriptional repression of AML-1 target genes is critical in the pathogenesis of AMLs. In the case of AML-1/ETO, overexpression of $A M L-1$ and anti $A M L-1 / E T O$ antisense oligonucleotides can induce differentiation in cells containing this fusion protein $(185,191)$. In analogy to the observations that have been made for PML$\operatorname{RAR} \alpha$ and PLZF-RAR $\alpha$, ETO has been found to interact with N-COR and mSIN3A, thereby recruiting histone deacetylases to repress transcription. This effect can be inhibited by histone deacetylase inhibitors $(95,192)$. Additionally, it has been found that critical domains that mediate the interaction 
of ETO with N-COR both when $A M L-1$ is fused to $E T O[\mathrm{t}(8 ; 21)(\mathrm{q} 22 ; \mathrm{q} 22)]$ and when it is fused to MTG16 [t(16;21)(q24;q22)] are highly conserved, suggesting that $\mathrm{t}(16 ; 21)$ $(\mathrm{q} 24 ; \mathrm{q} 22)$ equally represses transcription through the recruitment of HDACs. Besides CBF $\beta$, AML-1 associates with other transcription factors and regulators and activates transcription if bound to HATs (e.g., CBP and p300) (191) or represses transcription when it interacts with mSIN3 (192) (Fig. 3).

- Other than the indirect recruitment of HDAC with the assistance of protein complexes, which include mSIN3A, N-COR, and SMRT or Rb, several transcription factors (e.g., YY1) and regulators are able to recruit HDAC enzymes directly (reviewed in 21), thereby interfering with the generation of a functional initiation complex. These HDACassociated effects on transcriptional regulation may be abrogated by HDAC-inhibitors (trapoxin, trichostatin A, etc.). The retinoblastoma protein (RB), which is important in the induction of cell-cycle arrest under unfavorable growth conditions, mediates E2Fbound promoter repression through its interaction with HDACl. This binding of HDAC to RB has been highlighted by the observations that tumor-specific mutations found in RB disrupt its association with HDAC $(159,193,194)$ and that viral oncoproteins (e.g., HPV 16 E7 or the SV40 T-antigen) are able to displace HDAC from RB $(193,194)$. These findings suggest a fundamental role for histone modification in the suppression of cancer.

- So far, the chromosomal localizations of the human RPD3 orthologs HDAC1-3 $(102,195)$ and the HDAl orthologs HDAC4-7 have been identified more or less precisely (87) (Table 2) and, interestingly, HDACl-3 and HDAC7 localize to chromosomal sites, which are particularly fragile and frequently altered through mutations, translocations, and deletions, particularly in myeloproliferative disorders and solid tumors (101-103, 196). This may potentially result in a shift of the acetylation equilibrium toward acetylation.

It had long been epidemiologically postulated that a diet high in fiber was associated with a low incidence of colon cancer (197-200) until the Nurses' Health Study at Harvard, which was conducted on 88,757 middle-aged women, proved that the "protective effect" of dietary fiber against colorectal cancer or adenoma was not significant (198). Even though there is considerable and to some extent inconclusive literature on dietary fiber in connection with colon cancer, it appears that butyrate, a fiber fermentation product, could in fact have a protective effect against colon cancer (201-204). More recently, several investigators demonstrated that butyrate administration effectively reduced incidence and size of colonic tumors $(205,206)$, their likelihood to metastasize (207), and that it shifted their histological phenotype to one that appeared less aggressive (206). Even though the molecular mechanisms by which butyrate mediates its protective effects are still very unclear, butyrate has been shown to induce both histone and nonhistone hyperacetylation through a noncompetitive and nonspecific inhibition of HDACs via a serine-threonine protein phosphatase of the PPl type (208-210). In addition to its capability to induce differentiation, butyrate has been found to cause a Gl cell-cycle arrest $(211,212)$, which is mediated through induction of the Gl cellcycle inhibitor $p 21$ gene (213), thereby requiring an inhibition of HDACl. The fact that $p 21$ is deleted in the human colon carcinoma cell line HCT1116 further supports that p21 is essentially involved in butyrate-mediated cellular growth arrest (214). Because butyrate is rapidly metabolized and it has not been possible to maintain adequate butyrate concentrations in patients, butyrate homologs and alternative substrates [e.g., trichostatins and trapoxins $(215,216)$, depudecin (217), oxamflatin (218), benzamide derivatives (219)], which appear more promising than butyrate itself (e.g., phenylbutyrate and tributyrin) are currently under study (220-224).

\section{Conclusion and Future Directions}

The equilibrium of reversible histone acetylation is maintained by the activity of two families of enzymes, HATs and HDACs, which have been found to participate in the regulation of cellular proliferation and differentiation as cofactors of several mammalian transcriptional complexes. More recently, increasing evidence suggests a close connection between imbalanced histone acetylation and carcinogenesis. This goes hand in hand with the widely 


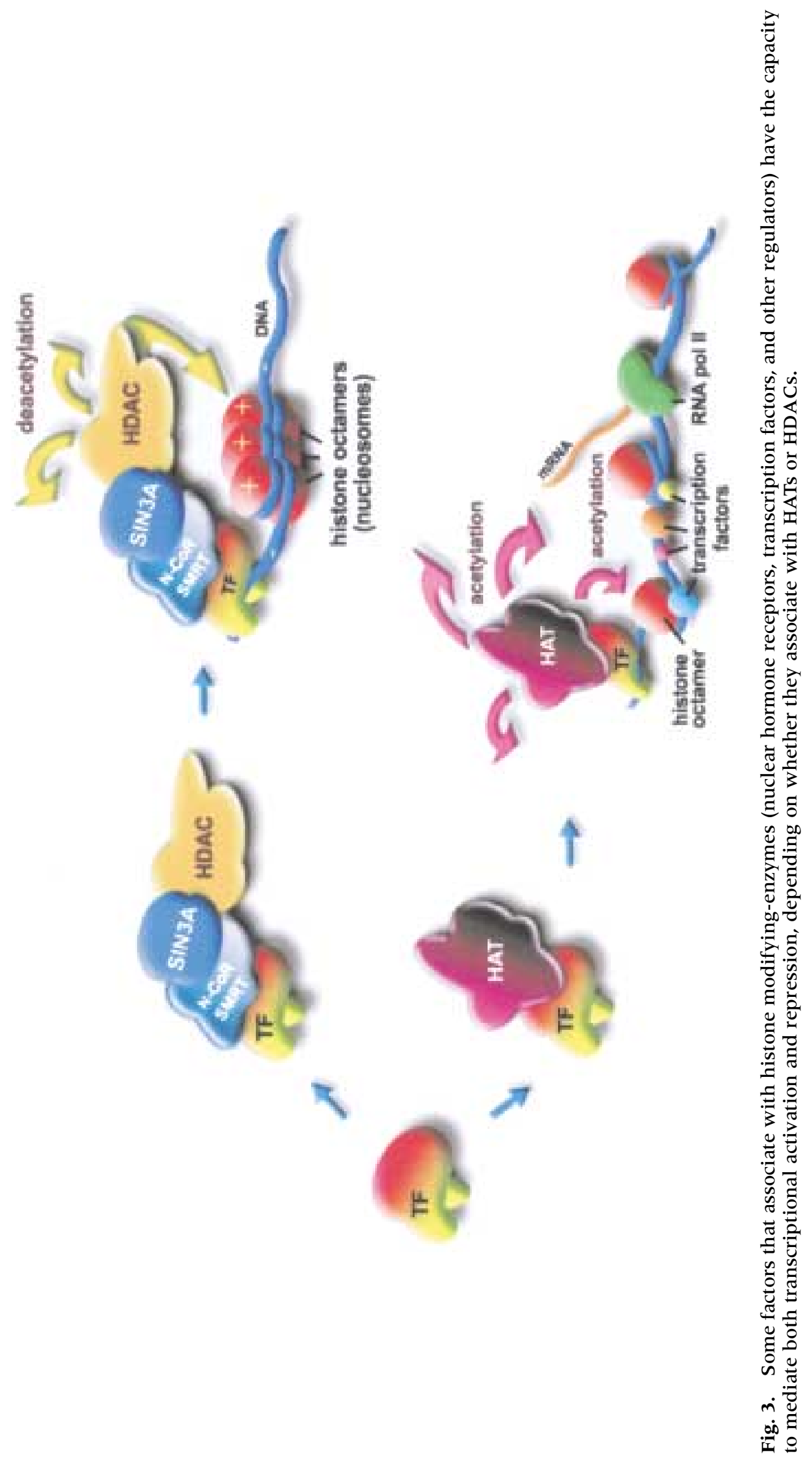


accepted concepts that reversible modification of chromatin influences its transcriptional competence and that promoters may be targeted specifically by either activating or repressing complexes. Histone acetylation modifiers have been found to be engaged and mutated in several types of cancer. Although genes encoding HAT enzymes have been found to be preferentially translocated, amplified, overexpressed, or point mutated, HDACS have repeatedly been identified to mediate the function of oncogenic translocation products, thereby accounting for at least $30 \%$ of AMLs, $25 \%$ of childhood BALLs, and more than $99 \%$ of APLs (26). They have also been found to associate with tumor suppressor proteins, which themselves are frequently mutated (e.g., RB). Many questions persist regarding the molecular mechanisms that involve histone-modifying enzymes. The further characterization of HATs and HDACs will therefore not only continue to unravel the role that these enzymes play in transcription, it will also help to identify the molecular mechanisms that promote leukemogenesis. Additionally, it looks like acetylation is not just limited to histones. It could therefore, in analogy to phosphorylation, be a process that influences the function of many proteins and cellular processes. The identification of proteins that interact with histone-modifying enzymes and target genes, which are misregulated as a consequence of mistargeted, or defective histonemodifying enzymes may help to hasten the development of less toxic, more refined and specific forms of pharmacological interventions for some forms of cancer and leukemias. First experiences with histone deacetylase inhibitors as "differentiation therapy" reagents have shown promising results for several types of leukemias $(96,172,221-224)$ and solid tumors $(220,225-227)$ with few, if any, significant side effects, indicating that such treatment could have great therapeutic advantages when compared to conventional chemotherapeutic agents. Even though almost explosive advances in the understanding of the molecular details of transcriptional regulation and chromatin modification through acetylation have been reported in the last few years, many questions remain. The identification of novel HAT/HDAC interaction targets, the analysis of HAT/HDAC levels in primary cells, and the response and tolerability of histone deacetylase inhibitors in patients may help to answer and generate new questions, such as how far a therapeutic modulation of intracellular acetylation levels could complement or replace existing chemotherapeutic strategies in the treatment of cancer.

\section{Acknowledgments}

We wish to apologize to those investigators whose relevant work was not discussed or cited directly in this manuscript due to space limitations. This work was partly supported by the German National Science Foundation (Deutsche Forschungsgemeinschaft, MA 2057/1-1) and institutional funds from the University of Frankfurt Medical Center.

\section{References}

1. Luger K, Mader AW, Richmond RK, et al. (1997) Crystal structure of the nucleosome core particle at 2.8 A resolution. Nature 389: 251-260.

2. Loidl P. (1994) Histone acetylation: facts and questions. Chromosoma 103: 441-449.

3. Jeppesen P. (1997) Histone acetylation: a possible mechanism for the inheritance of cell memory at mitosis. Bioessays 19: 67-74.

4. Wade PA, Pruss D, Wolffe AP. (1997) Histone acetylation: chromatin in action. Trends Biochem. Sci. 22: 128-132.

5. Struhl K. (1998) Histone acetylation and transcriptional regulatory mechanisms. Genes Dev. 12: 599-606.

6. Spencer VA, Davie JR. (1999) Role of covalent modifications of histones in regulating gene expression. Gene 240: 1-12.

7. Bradbury EM. (1992) Reversible histone modifications and the chromosome cell cycle. Bioessays 14: 9-16.

8. Barratt MJ, Hazzalin CA, Cano E, et al. (1994) Mitogen-stimulated phosphorylation of histone H3 is targeted to a small hyperacetylation-sensitive fraction. Proc. Natl. Acad. Sci. U.S.A. 91: 47814785.

9. Allfrey VG, Faulkner R, Mirsky AE. (1964) Acetylation and methylation of histones and their possible role in the regulation of RNA synthesis. Proc. Natl. Acad. Sci. U.S.A. 51: 786-794.

10. Cameron EE, Bachman KE, Myohanen S, et al. (1999) Synergy of demethylation and histone deacetylase inhibition in the re-expression of genes silenced in cancer. Nat. Genet. 21: 103-107.

11. Hebbes TR, Thorne AW, Crane-Robinson C. (1988) A direct link between core histone acetylation and transcriptionally active chromatin. Embo J. 7: 1395-1402.

12. Grunstein M. (1997) Histone acetylation in chromatin structure and transcription. Nature 389: 349-352. 
13. Braunstein M, Rose AB, Holmes SG, et al. (1993) Transcriptional silencing in yeast is associated with reduced nucleosome acetylation. Genes Dev. 7: 592-604.

14. Johnson CA, O'Neill LP, Mitchell A, et al. (1998) Distinctive patterns of histone $\mathrm{H} 4$ acetylation are associated with defined sequence elements within both heterochromatic and euchromatic regions of the human genome. Nucleic Acids Res. 26: 994-1001.

15. Ng HH, Bird A. (1999) DNA methylation and chromatin modification. Curr. Opin. Genet. Dev. 9: 158-163.

16. Nan $\mathrm{X}, \mathrm{Ng} \mathrm{HH}$, Johnson CA, et al. (1998) Transcriptional repression by the methyl-CpGbinding protein MeCP2 involves a histone deacetylase complex. Nature 393: 386-389.

17. Jones PL, Veenstra GJ, Wade PA, et al. (1998) Methylated DNA and MeCP2 recruit histone deacetylase to repress transcription. Nat. Genet. 19: 187-191.

18. Wong CW, Privalsky ML. (1998) Transcriptional repression by the SMRT-mSin3 corepressor: multiple interactions, multiple mechanisms, and a potential role for TFIIB. Mol. Cell. Biol. 18: 5500-5510.

19. Brownell JE, Zhou J, Ranalli T, et al. (1996) Tetrahymena histone acetyltransferase A: a homolog to yeast Gcn5p linking histone acetylation to gene activation. Cell 84: 843-851.

20. Kouzarides T. (1999) Histone acetylases and deacetylases in cell proliferation. Curr. Opin. Genet. Dev. 9: 40-48.

21. Davie JR, Chadee DN. (1998) Regulation and regulatory parameters of histone modifications. J. Cell. Biochem. Suppl. 31: 203-213.

22. Muscat GE, Burke LJ, Downes M. (1998) The corepressor N-CoR and its variants RIP13a and RIP13Deltal directly interact with the basal transcription factors TFIIB, TAFII32 and TAFII70. Nucleic Acids Res. 26: 2899-2907.

23. Boyes J, Byfield P, Nakatani Y, et al. (1998) Regulation of activity of the transcription factor GATA-1 by acetylation. Nature 396: 594-598.

24. Minucci S, Pelicci PG. (1999) Retinoid receptors in health and disease: co-regulators and the chromatin connection. Semin. Cell Dev. Biol. 10: 215-225.

25. Behre G, Zhang P, Zhang DE, et al. (1999) Analysis of the modulation of transcriptional activity in myelopoiesis and leukemogenesis. Methods 17: 231-237.

26. Fenrick R, Hiebert SW. (1998) Role of histone deacetylases in acute leukemia. J. Cell. Biochem. Suppl. 31: 194-202.

27. Magnaghi-Jaulin L, Ait-Si-Ali S, Harel-Bellan A. (1999) Histone acetylation in signal transduction by growth regulatory signals. Semin. Cell Dev. Biol. 10: 197-203.

28. Rundlett SE, Carmen AA, Kobayashi R, et al. (1996) HDAl and RPD3 are members of distinct yeast histone deacetylase complexes that regulate silencing and transcription. Proc. Natl. Acad. Sci. U.S.A. 93: 14503-14508.

29. Kleff S, Andrulis ED, Anderson CW, et al. (1995) Identification of a gene encoding a yeast histone $\mathrm{H} 4$ acetyltransferase. J. Biol. Chem. 270: 24674-24677.

30. Parthun MR, Widom J, Gottschling DE. (1996) The major cytoplasmic histone acetyltransferase in yeast: links to chromatin replication and histone metabolism. Cell 87: 85-94.

31. Chang L, Loranger SS, Mizzen C, et al. (1997) Histones in transit: cytosolic histone complexes and diacetylation of $\mathrm{H} 4$ during nucleosome assembly in human cells. Biochemistry 36: 469-480.

32. Kuo MH, Brownell JE, Sobel RE, et al. (1996) Transcription-linked acetylation by Gcn5p of histones H3 and H4 at specific lysines. Nature 383: 269-272.

33. Grant PA, Duggan L, Cote J, et al. (1997) Yeast Gcn5 functions in two multisubunit complexes to acetylate nucleosomal histones: characterization of an Ada complex and the SAGA (Spt/Ada) complex. Genes Dev. 11: 1640-1650.

34. Eberharter A, Sterner DE, Schieltz D, et al. (1999) The ADA complex is a distinct histone acetyltransferase complex in Saccharomyces cerevisiae. Mol. Cell. Biol. 19: 6621-6631.

35. Martinez E, Kundu TK, Fu J, et al. (1998) A human SPT3-TAFII31-GCN5-L acetylase complex distinct from transcription factor IID. J. Biol. Chem. 273: 23781-23785.

36. Bannister AJ, Kouzarides T. (1996) The CBP coactivator is a histone acetyltransferase. Nature 384: 641-643.

37. Ogryzko VV, Schiltz RL, Russanova V, et al. (1996) The transcriptional coactivators p300 and CBP are histone acetyltransferases. Cell 87: 953-959.

38. Yang XJ, Ogryzko VV, Nishikawa J, et al. (1996) A p300/CBP-associated factor that competes with the adenoviral oncoprotein ElA. Nature 382: 319-324.

39. Blanco JC, Minucci S, Lu J, et al. (1998) The histone acetylase PCAF is a nuclear receptor coactivator. Genes Dev. 12: 1638-1651.

40. Glass CK, Rose DW, Rosenfeld MG. (1997) Nuclear receptor coactivators. Curr. Opin. Cell Biol. 9: 222-232.

41. Chen H, Lin RJ, Schiltz RL, et al. (1997) Nuclear receptor coactivator ACTR is a novel histone acetyltransferase and forms a multimeric activation complex with P/CAF and CBP/p300. Cell 90: 569-580.

42. Spencer TE, Jenster G, Burcin MM, et al. (1997) Steroid receptor coactivator- 1 is a histone acetyltransferase. Nature 389: 194-198.

43. Onate SA, Tsai SY, Tsai MJ, et al. (1995) Sequence and characterization of a coactivator for 
the steroid hormone receptor superfamily. Science 270: 1354-1357.

44. Champagne N, Bertos NR, Pelletier N, et al. (1999) Identification of a human histone acetyltransferase related to monocytic leukemia zinc finger protein. J. Biol. Chem. 274: 28528-28536.

45. Smith ER, Eisen A, Gu W, et al. (1998) ESAl is a histone acetyltransferase that is essential for growth in yeast. Proc. Natl. Acad. Sci. U.S.A. 95: 3561-3565.

46. Kamine J, Elangovan B, Subramanian T, et al. (1996) Identification of a cellular protein that specifically interacts with the essential cysteine region of the HIV-1 Tat transactivator. Virology 216: 357-366.

47. Reifsnyder C, Lowell J, Clarke A, et al. (1996) Yeast SAS silencing genes and human genes associated with AML and HIV-1 Tat interactions are homologous with acetyltransferases. Nat. Genet. 14: 42-49.

48. Borrow J, Stanton VP, Jr., Andresen JM, et al. (1996) The translocation $t(8 ; 16)($ pl1;p13) of acute myeloid leukaemia fuses a putative acetyltransferase to the CREB-binding protein. Nat. Genet. 14: 33-41.

49. Hilfiker A, Hilfiker-Kleiner D, Pannuti A, et al. (1997) mof, a putative acetyl transferase gene related to the Tip60 and Moz human genes and to the Sas genes of yeast, is required for dosage compensation in Drosophila. Embo J. 16: 2054-2060.

50. Iizuka M, Stillman B. (1999) Histone acetyltransferase HBOl interacts with the ORCl subunit of the human initiator protein. J. Biol. Chem. 274: 23027-23034.

51. Yamamoto T, Horikoshi M. (1997) Novel substrate specificity of the histone acetyltransferase activity of HIV-1-Tat interactive protein Tip60. J. Biol. Chem. 272: 30595-30598.

52. Hsieh YJ, Kundu TK, Wang Z, et al. (1999) The TFIIIC90 subunit of TFIIIC interacts with multiple components of the RNA polymerase III machinery and contains a histone-specific acetyltransferase activity. Mol. Cell. Biol. 19: 7697-7704.

53. Kundu TK, Wang Z, Roeder RG. (1999) Human TFIIIC relieves chromatin-mediated repression of RNA polymerase III transcription and contains an intrinsic histone acetyltransferase activity. Mol. Cell. Biol. 19: 1605-1615.

54. Mizzen CA, Yang XJ, Kokubo T, et al. (1996) The TAF(II)250 subunit of TFIID has histone acetyltransferase activity. Cell 87: 1261-1270.

55. Ruiz-Garcia AB, Sendra R, Galiana $M$, et al. (1998) HAT1 and HAT2 proteins are components of a yeast nuclear histone acetyltransferase enzyme specific for free histone H4. J. Biol. Chem. 273: 12599-12605.

56. Ohba R, Steger DJ, Brownell JE, et al. (1999) A novel $\mathrm{H} 2 \mathrm{~A} / \mathrm{H} 4$ nucleosomal histone acetyltransferase in Tetrahymena thermophila. Mol. Cell. Biol. 19: 2061-2068.
57. Wittschieben BO, Otero G, de Bizemont $\mathrm{T}$, et al. (1999) A novel histone acetyltransferase is an integral subunit of elongating RNA polymerase II holoenzyme. Mol. Cell 4: 123-128.

58. Yao TP, Oh SP, Fuchs M, et al. (1998) Gene dosage-dependent embryonic development and proliferation defects in mice lacking the transcriptional integrator p300. Cell 93: 361-372.

59. Workman JL, Kingston RE. (1998) Alteration of nucleosome structure as a mechanism of transcriptional regulation. Annu. Rev. Biochem. 67: 545-579.

60. Grant PA, Berger SL. (1999) Histone acetyltransferase complexes. Semin. Cell Dev. Biol. 10: 169-177.

61. Boffa LC, Vidali G, Mann RS, et al. (1978) Suppression of histone deacetylation in vivo and in vitro by sodium butyrate. J. Biol. Chem. 253: 3364-3366.

62. Carmen AA, Rundlett SE, Grunstein M. (1996) HDAl and HDA3 are components of a yeast histone deacetylase (HDA) complex. J. Biol. Chem. 271: 15837-15844.

63. Vidal M, Gaber RF. (1991) RPD3 encodes a second factor required to achieve maximum positive and negative transcriptional states in Saccharomyces cerevisiae. Mol. Cell. Biol. 11: 6317-6327.

64. Kim S, Benguria A, Lai CY, et al. (1999) Modulation of life-span by histone deacetylase genes in saccharomyces cerevisiae. Mol. Biol. Cell 10: 3125-3136.

65. Vu QA, Zhang DE, Chroneos ZC, et al. (1987) Polyamines inhibit the yeast histone deacetylase. FEBS Lett. 220: 79-83.

66. Taunton J, Hassig CA, Schreiber SL. (1996) A mammalian histone deacetylase related to the yeast transcriptional regulator $\operatorname{Rpd} 3 \mathrm{p}$. Science 272: 408-411.

67. Yang WM, Inouye C, Zeng Y, et al. (1996) Transcriptional repression by YYl is mediated by interaction with a mammalian homolog of the yeast global regulator RPD3. Proc. Natl. Acad. Sci. U.S.A. 93: 12845-12850.

68. McKenzie EA, Kent NA, Dowell SJ, et al. (1993) The centromere and promoter factor, 1, CPF1, of Saccharomyces cerevisiae modulates gene activity through a family of factors including SPT2 1, RPD1 (SIN3), RPD3 and CCR4. Mol. Gen. Genet. 240: 374-386.

69. Vidal M, Strich R, Esposito RE, et al. (1991) $\mathrm{RPD} 1$ (SIN3/UME4) is required for maximal activation and repression of diverse yeast genes. Mol. Cell. Biol. 11: 6306-6316.

70. Pazin MJ, Kadonaga JT. (1997) What's up and down with histone deacetylation and transcription? Cell 89: 325-328.

71. Wolffe AP. (1997) Transcriptional control. Sinful repression. Nature 387: 16-17.

72. Ayer DE, Lawrence QA, Eisenman RN. (1995) Mad-Max transcriptional repression is mediated by ternary complex formation with mammalian homologs of yeast repressor Sin3. Cell 80: 767-776. 
73. Schreiber-Agus N, Chin L, Chen K, et al. (1995) An amino-terminal domain of Mxil mediates anti-Myc oncogenic activity and interacts with a homolog of the yeast transcriptional repressor SIN3. Cell 80: 777-786.

74. Hassig CA, Fleischer TC, Billin AN, et al. (1997) Histone deacetylase activity is required for full transcriptional repression by $\mathrm{mSin} 3 \mathrm{~A}$. Cell 89: 341-347.

75. Laherty CD, Yang WM, Sun JM, et al. (1997) Histone deacetylases associated with the mSin3 corepressor mediate mad transcriptional repression. Cell 89: 349-356.

76. Amati B, Dalton S, Brooks MW, et al. (1992) Transcriptional activation by the human c-Myc oncoprotein in yeast requires interaction with Max. Nature 359: 423-426.

77. Kretzner L, Blackwood EM, Eisenman RN. (1992) Myc and Max proteins possess distinct transcriptional activities. Nature 359: 426-429.

78. Chen JD, Evans RM. (1995) A transcriptional co-repressor that interacts with nuclear hormone receptors. Nature 377: 454-457.

79. Horlein AJ, Naar AM, Heinzel T, et al. (1995) Ligand-independent repression by the thyroid hormone receptor mediated by a nuclear receptor co-repressor. Nature 377: 397-404.

80. Alland L, Muhle R, Hou H, Jr., et al. (1997) Role for N-CoR and histone deacetylase in Sin3-mediated transcriptional repression. Nature 387: 49-55.

81. Heinzel T, Lavinsky RM, Mullen TM, et al. (1997) A complex containing $\mathrm{N}-\mathrm{CoR}, \mathrm{mSin} 3$ and histone deacetylase mediates transcriptional repression. Nature 387: 43-48.

82. Nagy L, Kao HY, Chakravarti D, et al. (1997) Nuclear receptor repression mediated by a complex containing SMRT, $\mathrm{mSin} 3 \mathrm{~A}$, and histone deacetylase. Cell 89: 373-380.

83. Kadosh D, Struhl K. (1997) Repression by Ume6 involves recruitment of a complex containing $\operatorname{Sin} 3$ corepressor and Rpd3 histone deacetylase to target promoters. Cell 89: 365-371.

84. Yang WM, Yao YL, Sun JM, et al. (1997) Isolation and characterization of cDNAs corresponding to an additional member of the human histone deacetylase gene family. J. Biol. Chem. 272: 28001-28007.

85. Emiliani S, Fischle W, Van Lint C, et al. (1998) Characterization of a human RPD3 ortholog, HDAC3. Proc. Natl. Acad. Sci. U.S.A. 95: 2795-2800.

86. Dangond F, Hafler DA, Tong JK, et al. (1998) Differential display cloning of a novel human histone deacetylase (HDAC3) cDNA from PHAactivated immune cells. Biochem. Biophys. Res. Commun. 242: 648-652.

87. Wang AH, Bertos NR, Vezmar M, et al. (1999) HDAC4, a human histone deacetylase related to yeast HDAl, is a transcriptional corepressor. Mol. Cell. Biol. 19: 7816-7827.
88. Grozinger CM, Hassig CA, Schreiber SL. (1999) Three proteins define a class of human histone deacetylases related to yeast Hdalp. Proc. Natl. Acad. Sci. U.S.A. 96: 4868-4873.

89. Shi Y, Seto E, Chang LS, et al. (1991) Transcriptional repression by YYl, a human GLIKruppel-related protein, and relief of repression by adenovirus E1A protein. Cell 67: 377-388.

90. Van Lint C, Emiliani S, Ott M, et al. (1996) Transcriptional activation and chromatin remodeling of the HIV-1 promoter in response to histone acetylation. Embo J. 15: 1112-1120.

91. Zhang Y, Iratni R, Erdjument-Bromage H, et al. (1997) Histone deacetylases and SAP18, a novel polypeptide, are components of a human Sin3 complex. Cell 89: 357-364.

92. Miska EA, Karlsson C, Langley E, et al. (1999) HDAC4 deacetylase associates with and represses the MEF2 transcription factor. Embo $J$. 18: $5099-5107$.

93. Aiba H, Kawaura R, Yamamoto E, et al. (1998) Isolation and characterization of highosmolarity-sensitive mutants of fission yeast. $J$. Bacteriol. 180: 5038-5043.

94. Carmen AA, Griffin PR, Calaycay JR, et al. (1999) Yeast HOS3 forms a novel trichostatin A-insensitive homodimer with intrinsic histone deacetylase activity. Proc. Natl. Acad. Sci. U.S.A. 96: 12356-12361.

95. Wang J, Hoshino T, Redner RL, et al. (1998) ETO, fusion partner in $t(8 ; 21)$ acute myeloid leukemia, represses transcription by interaction with the human $\mathrm{N}-\mathrm{CoR} / \mathrm{mSin} 3 / \mathrm{HDACl}$ complex. Proc. Natl. Acad. Sci. U.S.A. 95: 10860- 10865.

96. Wang J, Saunthararajah Y, Redner RL, et al. (1999) Inhibitors of histone deacetylase relieve ETO-mediated repression and induce differentiation of AMLl-ETO leukemia cells. Cancer Res. 59: 2766-2769.

97. Grignani F, De Matteis S, Nervi C, et al. (1998) Fusion proteins of the retinoic acid receptoralpha recruit histone deacetylase in promyelocytic leukaemia. Nature 391: 815-818.

98. Lin RJ, Nagy L, Inoue S, et al. (1998) Role of the histone deacetylase complex in acute promyelocytic leukaemia. Nature 391: 811-814.

99. Kosugi H, Towatari M, Hatano S, et al. (1999) Histone deacetylase inhibitors are the potent inducer/enhancer of differentiation in acute myeloid leukemia: a new approach to antileukemia therapy. Leukemia 13: 1316-1324.

100. Horiuchi K, Fujimoto D, Fukushima M, et al. (1981) Increased histone acetylation and deacetylation in rat ascites hepatoma cells. Cancer Res. 41: 1488-1491.

101. Le Beau MM, Espinosa Rd, Neuman WL, et al. (1993) Cytogenetic and molecular delineation of the smallest commonly deleted region of chromosome 5 in malignant myeloid diseases. Proc. Natl. Acad. Sci. U.S.A. 90: 5484-5488. 
102. Randhawa GS, Bell DW, Testa JR, et al. (1998) Identification and mapping of human histone acetylation modifier gene homologues. Genomics 51: 262-269.

103. Mahlknecht U, Bucala R, Hoelzer D, et al. (1999) High resolution physical mapping of human HDAC3, a potential tumor suppressor gene in the 5q31 region. Cytogenet. Cell Genet. 86: 237-239.

104. Anzick SL, Kononen J, Walker RL, et al. (1997) AIB 1, a steroid receptor coactivator amplified in breast and ovarian cancer. Science 277: 965-968.

105. Rowley JD, Reshmi S, Sobulo O, et al. (1997) All patients with the $\mathrm{T}(11 ; 16)(\mathrm{q} 23 ; \mathrm{p} 13.3)$ that involves MLL and CBP have treatmentrelated hematologic disorders. Blood 90: 535541.

106. Taki T, Sako M, Tsuchida M, et al. (1997) The $\mathrm{t}(11 ; 16)(\mathrm{q} 23 ; \mathrm{p} 13)$ translocation in myelodysplastic syndrome fuses the MLL gene to the CBP gene. Blood 89: 3945-3950.

107. Sobulo OM, Borrow J, Tomek R, et al. (1997) MLL is fused to CBP, a histone acetyltransferase, in therapy-related acute myeloid leukemia with a t(11;16)(q23;p13.3). Proc. Natl. Acad. Sci. U.S.A. 94: 8732-8737.

108. Satake N, Ishida Y, Otoh Y, et al. (1997) Novel MLL-CBP fusion transcript in therapy-related chronic myelomonocytic leukemia with a $\mathrm{t}(11 ; 16)(\mathrm{q} 23 ; \mathrm{p} 13)$ chromosome translocation. Genes Chromosomes Cancer 20: 60-63.

109. Quesnel B, Kantarjian H, Bjergaard JP, et al. (1993) Therapy-related acute myeloid leukemia with $t(8 ; 21)$, inv(16), and $t(8 ; 16)$ : a report on 25 cases and review of the literature. J. Clin. Oncol. 11: 2370-2379.

110. Dutnall RN, Tafrov ST, Sternglanz R, et al. (1998) Structure of the histone acetyltransferase Hatl: a paradigm for the GCN5-related Nacetyltransferase superfamily. Cell 94: 427-438.

111. Mahlknecht U, Ottmann OG, Hoelzer D. (2000) When the band begins to play: Histone acetylation caught in the crossfire of gene control. Mol. Carcinog. (in press).

112. Lee SK, Anzick SL, Choi JE, et al. (1999) A nuclear factor, ASC-2, as a cancer-amplified transcriptional coactivator essential for ligand-dependent transactivation by nuclear receptors in vivo. J. Biol. Chem. 274: 34283-34293.

113. Imhof A, Yang XJ, Ogryzko VV, et al. (1997) Acetylation of general transcription factors by histone acetyltransferases. Curr. Biol. 7: 689692.

114. Boyes J, Byfield P, Nakatani Y, et al. (1998) Regulation of activity of the transcription factor GATA-1 by acetylation. Nature 396: 594-598.

115. Zhang W, Bieker JJ. (1998) Acetylation and modulation of erythroid Kruppel-like factor (EKLF) activity by interaction with histone acetyltransferases. Proc. Natl. Acad. Sci. U.S.A. 95: 9855-9860.
116. Gu W, Roeder RG. (1997) Activation of p53 sequence-specific DNA binding by acetylation of the p53 C-terminal domain. Cell 90: 595-606.

117. Sakaguchi K, Herrera JE, Saito S, et al. (1998) DNA damage activates p53 through a phosphorylation-acetylation cascade. Genes Dev. 12: $2831-$ 2841.

118. Perkins ND, Felzien LK, Betts JC, et al. (1997) Regulation of NF-kappaB by cyclin-dependent kinases associated with the p300 coactivator. Science 275: 523-527.

119. Munshi N, Merika M, Yie J, et al. (1998) Acetylation of HMG I(Y) by CBP turns off IFN beta expression by disrupting the enhanceosome. Mol. Cell 2: 457-467.

120. Feng XH, Zhang Y, Wu RY, et al. (1998) The tumor suppressor Smad4/DPC4 and transcriptional adaptor $\mathrm{CBP} / \mathrm{p} 300$ are coactivators for smad3 in TGF-beta-induced transcriptional activation. Genes Dev. 12: 2153-2163.

121. Janknecht R, Wells NJ, Hunter T. (1998) TGFbeta-stimulated cooperation of smad proteins with the coactivators CBP/p300. Genes Dev. 12: 2114-2119.

122. Luo K, Stroschein SL, Wang W, et al. (1999) The Ski oncoprotein interacts with the Smad proteins to repress TGFbeta signaling. Genes Dev. 13: 2196-2206.

123. Janknecht R, Hunter T. (1996) Transcription. A growing coactivator network. Nature 383: 22-23.

124. Avantaggiati ML, Ogryzko V, Gardner K, et al. (1997) Recruitment of p300/CBP in p53-dependent signal pathways. Cell 89: 1175-1184.

125. Martinez-Balbas MA, Bannister AJ, Martin K, et al. (1998) The acetyltransferase activity of CBP stimulates transcription. Embo J. 17: 28862893.

126. Zhou S, Buckhaults P, Zawel L, et al. (1998) Targeted deletion of Smad4 shows it is required for transforming growth factor beta and activin signaling in colorectal cancer cells. Proc. Natl. Acad. Sci. U.S.A. 95: 2412-2416.

127. Muraoka M, Konishi M, Kikuchi-Yanoshita R, et al. (1996) p300 gene alterations in colorectal and gastric carcinomas. Oncogene 12: 15651569.

128. Giles RH, Peters DJ, Breuning MH. (1998) Conjunction dysfunction: $\mathrm{CBP} / \mathrm{p} 300$ in human disease. Trends Genet. 14: 178-183.

129. Aguiar RC, Chase A, Coulthard S, et al. (1997) Abnormalities of chromosome band 8 p 11 in leukemia: two clinical syndromes can be distinguished on the basis of MOZ involvement. Blood 90: 3130-3135.

130. Giordano A, Avantaggiati ML. (1999) p300 and CBP: partners for life and death. J. Cell Physiol. 181: 218-230.

131. Arany Z, Newsome D, Oldread E, et al. (1995) A family of transcriptional adaptor proteins targeted by the E1A oncoprotein. Nature 374: 81-84. 
132. Lundblad JR, Kwok RP, Laurance ME, et al. (1995) Adenoviral ElA-associated protein p300 as a functional homologue of the transcriptional co-activator CBP. Nature 374: 8588.

133. Eckner R, Ludlow JW, Lill NL, et al. (1996) Association of $\mathrm{p} 300$ and CBP with simian virus 40 large T antigen. Mol. Cell. Biol. 16: 3454-3464.

134. Carapeti M, Aguiar RC, Goldman JM, et al. (1998) A novel fusion between MOZ and the nuclear receptor coactivator TIF2 in acute myeloid leukemia. Blood 91: 3127-3133.

135. Liang J, Prouty L, Williams BJ, et al. (1998) Acute mixed lineage leukemia with an $\operatorname{inv}(8)(p 11 q 13)$ resulting in fusion of the genes for MOZ and TIF2. Blood 92: 2118-2122.

136. Voegel JJ, Heine MJ, Zechel C, et al. (1996) TIF2, a $160 \mathrm{kDa}$ transcriptional mediator for the ligand-dependent activation function AF-2 of nuclear receptors. Embo J. 15: 3667-3675.

137. Voegel JJ, Heine MJ, Tini M, et al. (1998) The coactivator TIF2 contains three nuclear receptor-binding motifs and mediates transactivation through CBP binding-dependent and -independent pathways. Embo J. 17: 507-519.

138. Ida K, Kitabayashi I, Taki T, et al. (1997) Adenoviral ElA-associated protein p300 is involved in acute myeloid leukemia with $\mathrm{t}(11 ; 22)(\mathrm{q} 23 ; \mathrm{q} 13)$. Blood 90: 4699-4704.

139. Stassen MJ, Bailey D, Nelson S, et al. (1995) The Drosophila trithorax proteins contain a novel variant of the nuclear receptor type DNA binding domain and an ancient conserved motif found in other chromosomal proteins. Mech. Dev. 52: 209-223.

140. Nislow C, Ray E, Pillus L. (1997) SET1, A Yeast Member of the Trithorax Family, Functions in Transcriptional Silencing and Diverse Cellular Processes. Mol. Biol. Cell 8: 242 1-2436.

141. Rozenblatt-Rosen O, Rozovskaia T, Burakov D, et al. (1998) The C-terminal SET domains of ALL- 1 and TRITHORAX interact with the INII and SNRI proteins, components of the SWI/SNF complex. Proc. Natl. Acad. Sci. U.S.A. 95: 4152-4157.

142. Pollard KJ, Peterson CL. (1998) Chromatin remodeling: a marriage between two families? Bioessays 20: 771-780.

143. Welch MD, Drubin DG. (1994) A nuclear protein with sequence similarity to proteins implicated in human acute leukemias is important for cellular morphogenesis and actin cytoskeletal function in Saccharomyces cerevisiae. Mol. Biol. Cell 5: 617-632.

144. Jacobson S, Pillus L. (1999) Modifying chromatin and concepts of cancer. Curr. Opin. Genet. Dev. 9: 175-184.

145. Rubnitz JE, Morrissey J, Savage PA, et al. (1994) ENL, the gene fused with HRX in $t(11 ; 19)$ leukemias, encodes a nuclear protein with transcriptional activation potential in lymphoid and myeloid cells. Blood 84: 17471752.

146. Prasad R, Yano T, Sorio C, et al. (1995) Domains with transcriptional regulatory activity within the ALLl and AF4 proteins involved in acute leukemia. Proc. Natl. Acad. Sci. U.S.A. 92: 12160-12164.

147. Versteege I, Sevenet N, Lange J, et al. (1998) Truncating mutations of hSNF5/INIl in aggressive paediatric cancer. Nature 394: 203-206.

148. Petrij F, Giles RH, Dauwerse HG, et al. (1995) Rubinstein-Taybi syndrome caused by mutations in the transcriptional co-activator CBP. Nature 376: 348-351.

149. Tanaka Y, Naruse I, Maekawa T, et al. (1997) Abnormal skeletal patterning in embryos lacking a single Cbp allele: a partial similarity with Rubinstein-Taybi syndrome. Proc. Natl. Acad. Sci. U.S.A. 94: 10215-10220.

150. Kamei Y, Xu L, Heinzel T, et al. (1996) A CBP integrator complex mediates transcriptional activation and AP-1 inhibition by nuclear receptors. Cell 85: 403-414.

151. Gu W, Shi XL, Roeder RG. (1997) Synergistic activation of transcription by CBP and p53. $\mathrm{Na}$ ture 387: 819-823.

152. Lill NL, Grossman SR, Ginsberg D, et al. (1997) Binding and modulation of p53 by p300/CBP coactivators. Nature 387: 823-827.

153. Arias J, Alberts AS, Brindle P, et al. (1994) Activation of cAMP and mitogen responsive genes relies on a common nuclear factor. Nature 370: 226-229.

154. Angel P, Karin M. (1991) The role of Jun, Fos and the AP-1 complex in cell-proliferation and transformation. Biochim. Biophys. Acta. 10: 2-3.

155. Lee JS, See RH, Deng T, et al. (1996) Adenovirus ElA downregulates cJun- and JunB-mediated transcription by targeting their coactivator $\mathrm{p} 300$. Mol. Cell. Biol. 16: 4312-4326.

156. Yuan W, Condorelli G, Caruso M, et al. (1996) Human p300 protein is a coactivator for the transcription factor MyoD. J. Biol. Chem. 271: 9009-9013.

157. Chakravarti D, LaMorte VJ, Nelson MC, et al. (1996) Role of CBP/P300 in nuclear receptor signalling. Nature 383: 99-103.

158. DePinho RA. (1998) Transcriptional repression. The cancer-chromatin connection. Nature 391: 535-536.

159. Luo RX, Postigo AA, Dean DC. (1998) Rb interacts with histone deacetylase to repress transcription. Cell 92: 463-473.

160. McMahon SB, Wood MA, Cole MD. (2000) The essential cofactor TRRAP recruits the histone acetyltransferase hGCN5 to c-Myc. Mol. Cell. Biol. 20: 556-562.

161. Zhong H, Voll RE, Ghosh S. (1998) Phosphorylation of NF-kappa B p65 by PKA stimulates transcriptional activity by promoting a novel 
bivalent interaction with the coactivator CBP/p300. Mol. Cell 1: 661-671.

162. Merika M, Williams AJ, Chen G, et al. (1998) Recruitment of CBP/p300 by the IFN beta enhanceosome is required for synergistic activation of transcription. Mol. Cell 1: 277-287.

163. Ruddon RW. (1995). Genetic alterations in cancer cells. In: Cancer Biology. Oxford University Press, New York, pp 91-95.

164. Look AT. (1997) Oncogenic transcription factors in the human acute leukemias. Science 278: 1059-1064.

165. de The H, Chomienne C, Lanotte $M$, et al. (1990) The $t(15 ; 17)$ translocation of acute promyelocytic leukaemia fuses the retinoic acid receptor alpha gene to a novel transcribed locus. Nature 347: 558-561.

166. Borrow J, Goddard AD, Sheer D, et al. (1990) Molecular analysis of acute promyelocytic leukemia breakpoint cluster region on chromosome 17. Science 249: 1577-1580.

167. Kalantry S, Delva L, Gaboli M, et al. (1997) Gene rearrangements in the molecular pathogenesis of acute promyelocytic leukemia. J. Cell Physiol. 173: 288-296.

168. Najfeld V, Scalise A, Troy K. (1989) A new variant translocation $11 ; 17$ in a patient with acute promyelocytic leukemia together with $\mathrm{t}(7 ; 12)$. Cancer Genet. Cytogenet. 43: 103-108.

169. Licht JD, Chomienne C, Goy A, et al. (1995) Clinical and molecular characterization of a rare syndrome of acute promyelocytic leukemia associated with translocation $(11 ; 17)$. Blood 85: 1083-1094.

170. Li JY, English MA, Ball HJ, et al. (1997) Sequence-specific DNA binding and transcriptional regulation by the promyelocytic leukemia zinc finger protein. J. Biol. Chem. 272: 22447-22455.

171. Grimwade D, Solomon E. (1997) Characterisation of the PML/RAR alpha rearrangement associated with $\mathrm{t}(15 ; 17)$ acute promyelocytic leukaemia. Curr. Top. Microbiol. Immunol. 220: 81-112.

172. He LZ, Guidez F, Tribioli C, et al. (1998) Distinct interactions of PML-RARalpha and PLZFRARalpha with co- repressors determine differential responses to RA in APL. Nat. Genet. 18: 126-135.

173. Kurokawa R, Soderstrom M, Horlein A, et al. (1995) Polarity-specific activities of retinoic acid receptors determined by a co-repressor. Nature 377: 451-454.

174. Nakajima H, Kim YB, Terano H, et al. (1998) FR901228, a potent antitumor antibiotic, is a novel histone deacetylase inhibitor. Exp. Cell Res. 241: 126-133.

175. Richon VM, Emiliani S, Verdin E, et al. (1998) A class of hybrid polar inducers of transformed cell differentiation inhibits histone deacetylases. Proc. Natl. Acad. Sci. U.S.A. 95: 3003-3007.
176. Ohki M. (1993) Molecular basis of the $t(8 ; 21)$ translocation in acute myeloid leukaemia. Semin. Cancer Biol. 4: 369-375.

177. Nucifora G, Rowley JD. (1995) AMLl and the $8 ; 21$ and 3;21 translocations in acute and chronic myeloid leukemia. Blood 86: 1-14.

178. Lenny N, Westendorf JJ, Hiebert SW. (1997) Transcriptional regulation during myelopoiesis. Mol. Biol. Rep. 24: 157-168.

179. Berger R, Le Coniat M, Romana SP, et al. (1996) Secondary acute myeloblastic leukemia with $\mathrm{t}(16 ; 21)(\mathrm{q} 24 ; \mathrm{q} 22)$. involving the AML1 gene. Hematol. Cell Ther. 38: 183-186.

180. Shimada M, Ohtsuka E, Shimizu T, et al. (1997) A recurrent translocation, $\mathrm{t}(16 ; 21)(\mathrm{q} 24 ; \mathrm{q} 22)$, associated with acute myelogenous leukemia: identification by fluorescence in situ hybridization. Cancer Genet. Cytogenet. 96: 102-105.

181. Gamou T, Kitamura E, Hosoda F, et al. (1998) The partner gene of AMLl in $t(16 ; 21)$ myeloid malignancies is a novel member of the MTG8(ETO) family. Blood 91: 4028-4037.

182. Horsman DE, Gascoyne RD, Barnett MJ. (1995) Acute leukemia with structural rearrangements of chromosome 3. Leuk. Lymphoma 16: 369-377.

183. Secker-Walker LM, Mehta A, Bain B. (1995) Abnormalities of $3 \mathrm{q} 21$ and $3 \mathrm{q} 26$ in myeloid malignancy: a United Kingdom Cancer Cytogenetic Group study. Br. J. Haematol. 91: 490501.

184. Speck NA, Terryl S. (1995) A new transcription factor family associated with human leukemias. Crit. Rev. Eukaryot. Gene Expr. 5: 337-364.

185. Meyers S, Hiebert SW. (1995) Indirect and direct disruption of transcriptional regulation in cancer: E2F and AML-1. Crit. Rev. Eukaryot. Gene Expr. 5: 365-383.

186. Romana SP, Poirel H, Leconiat M, et al. (1995) High frequency of $t(12 ; 21)$ in childhood B-lineage acute lymphoblastic leukemia. Blood 86: 4263-4269.

187. Raynaud S, Cave H, Baens M, et al. (1996) The 12;21 translocation involving TEL and deletion of the other TEL allele: two frequently associated alterations found in childhood acute lymphoblastic leukemia. Blood 87: 2891-2899.

188. Westendorf JJ, Yamamoto CM, Lenny N, et al. (1998) The $t(8 ; 21)$ fusion product, AML-1ETO, associates with C/EBP-alpha, inhibits C/EBP-alpha-dependent transcription, and blocks granulocytic differentiation. Mol. Cell. Biol. 18: 322-333.

189. Tanaka T, Tanaka K, Ogawa S, et al. (1995) An acute myeloid leukemia gene, AML1, regulates hemopoietic myeloid cell differentiation and transcriptional activation antagonistically by two alternative spliced forms. Embo J. 14: 341-350. 
190. Niitsu N, Yamamoto-Yamaguchi Y, Miyoshi H, et al. (1997) AMLla but not AMLlb inhibits erythroid differentiation induced by sodium butyrate and enhances the megakaryocytic differentiation of K562 leukemia cells. Cell Growth Differ. 8: 319-326.

191. Kitabayashi I, Yokoyama A, Shimizu K, et al. (1998) Interaction and functional cooperation of the leukemia-associated factors AMLl and p300 in myeloid cell differentiation. Embo J. 17: 2994-3004.

192. Lutterbach B, Westendorf JJ, Linggi B, et al. (1998) ETO, a target of $t(8 ; 21)$ in acute leukemia, interacts with the N-CoR and $\mathrm{mSin} 3$ corepressors. Mol. Cell. Biol. 18: 7176-7184.

193. Brehm A, Miska EA, McCance DJ, et al. (1998) Retinoblastoma protein recruits histone deacetylase to repress transcription. Nature 391: 597-601.

194. Magnaghi-Jaulin L, Groisman R, Naguibneva I, et al. (1998) Retinoblastoma protein represses transcription by recruiting a histone deacetylase. Nature 391: 601-605.

195. Mahlknecht U, Emiliani S, Najfeld V, et al. (1999) Genomic organization and chromosomal localization of the human histone deacetylase 3 gene. Genomics 56: 197-202.

196. Wlodarska I, De Wolf-Peeters C, Michaux L, et al. (1995) A new $t(2 ; 5)$ translocation in a null cell type CD30 positive anaplastic large cell lymphoma case. Leukemia 9: 1685-1688.

197. Burkitt DP. (1971) Epidemiology of cancer of the colon and rectum. Cancer 28: 3-13.

198. Fuchs CS, Giovannucci EL, Colditz GA, et al. (1999) Dietary fiber and the risk of colorectal cancer and adenoma in women. N. Engl. J. Med. 340: 169-176.

199. Wargovich MJ, Levin B. (1996) Grist for the mill: role of cereal fiber and calcium in prevention of colon cancer. J. Natl. Cancer Inst. 88: 67-69.

200. Zoran DL, Turner ND, Taddeo SS, et al. (1997) Wheat bran diet reduces tumor incidence in a rat model of colon cancer independent of effects on distal luminal butyrate concentrations. J. Nutr. 127: 2217-2225.

201. Folino M, McIntyre A, Young GP. (1995) Dietary fibers differ in their effects on large bowel epithelial proliferation and fecal fermentationdependent events in rats. J. Nutr. 125: 15211528.

202. DeCosse JJ, Miller HH, Lesser ML. (1989) Effect of wheat fiber and vitamins $C$ and $E$ on rectal polyps in patients with familial adenomatous polyposis. J. Natl. Cancer Inst. 81: $1290-1297$.

203. Weaver GA, Krause JA, Miller TL, et al. (1988) Short chain fatty acid distributions of enema samples from a sigmoidoscopy population: an association of high acetate and low butyrate ratios with adenomatous polyps and colon cancer. Gut 29: 1539-1543.

204. Clausen MR, Bonnen H, Mortensen PB. (1991) Colonic fermentation of dietary fibre to short chain fatty acids in patients with adenomatous polyps and colonic cancer. Gut 32: 923-928.

205. D'Argenio G, Cosenza V, Delle Cave M, et al. (1996) Butyrate enemas in experimental colitis and protection against large bowel cancer in a rat model. Gastroenterology 110: 1727-1734.

206. Medina V, Afonso JJ, Alvarez-Arguelles H, et al. (1998) Sodium butyrate inhibits carcinoma development in a 1,2- dimethylhydrazineinduced rat colon cancer. JPEN J. Parenter. Enteral Nutr. 22: 14-17.

207. Velazquez OC, Jabbar A, DeMatteo RP, et al. (1996) Butyrate inhibits seeding and growth of colorectal metastases to the liver in mice. Surgery 120: 440-447.

208. Sealy L, Chalkley R. (1978) The effect of sodium butyrate on histone modification. Cell 14: 115-121.

209. Boffa LC, Lupton JR, Mariani MR, et al. (1992) Modulation of colonic epithelial cell proliferation, histone acetylation, and luminal short chain fatty acids by variation of dietary fiber (wheat bran) in rats. Cancer Res. 52: 59065912.

210. Cuisset L, Tichonicky L, Delpech M. (1998) A protein phosphatase is involved in the inhibition of histone deacetylation by sodium butyrate. Biochem. Biophys. Res. Commun. 246: 760-764.

211. Barnard JA, Warwick G. (1993) Butyrate rapidly induces growth inhibition and differentiation in HT-29 cells. Cell Growth Differ. 4: 495-501.

212. Yoshida M, Beppu T. (1988) Reversible arrest of proliferation of rat 3Yl fibroblasts in both the G1 and G2 phases by trichostatin A. Exp. Cell Res. 177: 122-131.

213. Archer SY, Meng S, Shei A, et al. (1998) p2 1 (Waf 1 ) is required for butyrate-mediated growth inhibition of human colon cancer cells. Proc. Natl. Acad. Sci. U. S. A. 95: 6791-6796.

214. Archer SY, Hodin RA. (1999) Histone acetylation and cancer. Curr. Opin. Genet. Dev. 9: 171174.

215. Kijima M, Yoshida M, Sugita K, et al. (1993) Trapoxin, an antitumor cyclic tetrapeptide, is an irreversible inhibitor of mammalian histone deacetylase. J. Biol. Chem. 268: 2242922435.

216. Yoshida M, Kijima M, Akita M, et al. (1990) Potent and specific inhibition of mammalian histone deacetylase both in vivo and in vitro by trichostatin A. J. Biol. Chem. 265: 1717417179.

217. Kwon HJ, Owa T, Hassig CA, et al. (1998) Depudecin induces morphological reversion of transformed fibroblasts via the inhibition of 
histone deacetylase. Proc. Natl. Acad. Sci. U.S.A. 95: 3356-3361.

218. Kim YB, Lee KH, Sugita K, et al. (1999) Oxamflatin is a novel antitumor compound that inhibits mammalian histone deacetylase. Oncogene 18: 2461-2470.

219. Saito A, Yamashita T, Mariko Y, et al. (1999) A synthetic inhibitor of histone deacetylase, MS27-275, with marked in vivo antitumor activity against human tumors. Proc. Natl. Acad. Sci. U.S.A. 96: 4592-4597.

220. Samid D, Hudgins WR, Shack S, et al. (1997) Phenylacetate and phenylbutyrate as novel, nontoxic differentiation inducers. Adv. Exp. Med. Biol. 400A: 501-505.

221. Warrell RP, Jr., He LZ, Richon V, et al. (1998) Therapeutic targeting of transcription in acute promyelocytic leukemia by use of an inhibitor of histone deacetylase. J. Natl. Cancer Inst. 90: 1621-1625.

222. Lea MA, Tulsyan N. (1995) Discordant effects of butyrate analogues on erythroleukemia cell proliferation, differentiation and histone deace-tylase. Anticancer Res. 15: 879-883.

223. Lea MA, Randolph VM, Hodge SK. (1999) Induction of histone acetylation and growth regulation in eryrthroleukemia cells by 4-phenylbutyrate and structural analogs. Anticancer Res. 19: 1971-1976.

224. Saunders N, Dicker A, Popa C, et al. (1999) Histone deacetylase inhibitors as potential antiskin cancer agents. Cancer Res. 59: 399-404.

225. Engelhard HH, Duncan HA, Dal Canto M. (1997) Molecular characterization of glioblastoma cell differentiation. Neurosurgery 41: 886896.

226. Huang H, Reed CP, Zhang JS, et al. (1999) Carboxypeptidase A3 (CPA3): a novel gene highly induced by histone deacetylase inhibitors during differentiation of prostate epithelial cancer cells. Cancer Res. 59: 2981-2988.

227. Ellerhorst J, Nguyen $T$, Cooper DN, et al. (1999) Induction of differentiation and apoptosis in the prostate cancer cell line LNCaP by sodium butyrate and galectin-1. Int. J. Oncol. 14: 225-232.

228. Keohane AM, LP On, Belyaev ND, et al. (1996) $\mathrm{X}$-Inactivation and histone $\mathrm{H} 4$ acetylation in embryonic stem cells. Dev. Biol. 180: 618-630.

229. Braunstein M, Sobel RE, Allis CD, et al. (1996) Efficient transcriptional silencing in Saccharomyces cerevisiae requires a heterochromatin histone acetylation pattern. Mol. Cell Biol. 16: 4349-4356.

230. Moens PB. (1995) Histones Hl and H4 of surface-spread meiotic chromosomes. Chromosoma 104: 169-174.

231. Lee DY, Hayes JJ, Pruss D, et al. (1993) A positive role for histone acetylation in transcription factor access to nucleosomal DNA. Cell 72: 73-84.
232. Mutskov V, Gerber D, Angelov D, et al. (1998) Persistent interactions of core histone tails with nucleosomal DNA following acetylation and transcription factor binding. Mol. Cell Biol. 18: 6293-6304.

233. Vettese-Dadey M, Grant PA, Hebbes TR, et al. (1996) Acetylation of histone H4 plays a primary role in enhancing transcription factor binding to nucleosomal DNA in vitro. Embo $J$. 15: 2508-2518.

234. Rundlett SE, Carmen AA, Suka N, et al. (1998) Transcriptional repression by UME6 involves deacetylation of lysine 5 of histone $\mathrm{H} 4$ by RPD3. Nature 392: 831-835.

235. Ait-Si-Ali S, Ramirez S, Barre FX, et al. (1998) Histone acetyltransferase activity of CBP is controlled by cycle-dependent kinases and oncoprotein E1A. Nature 396: 184-186.

236. Cosma MP, Tanaka T, Nasmyth K. (1999) Ordered recruitment of transcription and chromatin remodeling factors to a cell cycle- and developmentally regulated promoter. Cell 97: 299-311.

237. Kao HY, Downes M, Ordentlich P, et al. (2000) Isolation of a novel histone deacetylase reveals that class I and class II deacetylases promote SMRT-mediated repression. Genes Dev. 14: 5566.

238. Akiyoshi S, Inoue H, Hanai J, et al. (1999) cSki acts as a Transcriptional Co-repressor in Transforming Growth Factor-beta Signaling through interaction with Smads. J. Biol. Chem. 274: 35269-35277.

239. Torchia J, Glass C, Rosenfeld MG. (1998) Coactivators and co-repressors in the integration of transcriptional responses. Curr. Opin. Cell Biol. 10: $373-383$.

240. Davie JR, Spencer VA. (1999) Control of histone modifications. J. Cell Biochem. 33: 141-148.

241. Bauer A, Mikulits W, Lagger G, et al. (1998) The thyroid hormone receptor functions as a ligand-operated developmental switch between proliferation and differentiation of erythroid progenitors. Embo J. 17: 4291-4303.

242. Bartl S, Taplick J, Lagger G, et al. (1997) Identification of mouse histone deacetylase 1 as a growth factor-inducible gene. Mol. Cell Biol. 17: 5033-5043.

243. Allard S, Utley RT, Savard J, et al. (1999) NuA4, an essential transcription adaptor/histone $\mathrm{H} 4$ acetyltransferase complex containing esalp and the ATM-related cofactor tralp. Embo J. 18: 5108-5119.

244. Clarke AS, Lowell JE, Jacobson SJ, et al. (1999) Esalp is an essential histone acetyltransferase required for cell cycle progression. Mol. Cell Biol. 19: 2515-2526.

245. Zhang W, Bone JR, Edmondson DG, et al. (1998) Essential and redundant functions of histone acetylation revealed by mutation of 
target lysines and loss of the Gcn5p acetyltransferase. Embo J. 17: 3155-3167.

246. Dunphy EL, Johnson T, Auerbach SS, et al. (2000) Requirement for TAF(II)250 Acetyltransferase Activity in Cell Cycle Progression. Mol. Cell Biol. 20: 1134-1139.

247. Kasten MM, Dorland S, Stillman DJ. (1997) A large protein complex containing the yeast Sin $3 p$ and $\operatorname{Rpd} 3 p$ transcriptional regulators. Mol. Cell Biol. 17: 4852-4858.

248. Kim S, Benguria A, Lai CY, et al. (1999) Modulation of life-span by histone deacetylase genes in Saccharomyces cerevisiae. Mol. Biol. Cell 10: 3125-3136. 